\title{
ARTICLE
}

\section{Acridinone-based anion transporters $†$}

\author{
Daniel A. McNaughton, ${ }^{a}$ Lauren K. Macreadie ${ }^{a}$ and Philip A. Gale ${ }^{* a, b}$
}

Received 00th January 20xx, Accepted 00th January 20xx

DOI: $10.1039 / x 0 \times x 00000 x$
The arrangement of hydrogen bond donors around a central lipophilic scaffold has proven a successful strategy in the development of potent chloride transporters. In this work, we revisit an acridinone 1,9-bis(thio)urea motif which had previously shown promise as an anion sensor and expand the series of compounds by appending a variety of electronwithdrawing groups to the peripheral phenyl moieties. High levels of activity were achieved by the most effective compounds in the series, which facilitated strictly electroneutral transport.

\section{Introduction}

The discovery of transmembrane anion transporters continues apace ${ }^{1}$ driven by the potential application of these compounds in the treatment of diseases such as cancer ${ }^{2}$ and cystic fibrosis. ${ }^{3}$ A successful strategy to design anionophores is to append hydrogen bond donor groups to a lipophilic scaffold. Examples include cholapods, ${ }^{4}$ ortho-phenylenes, ${ }^{5}$ trans-decalins, ${ }^{6}$ and anthracenes. ${ }^{7}$ We have previously shown that there is an optimal log $\mathrm{P}$ for each class of anion transporter. ${ }^{8,9}$ Compounds with a low log $P$ value may not be able to efficiently partition into a lipid bilayer whilst compounds with a high log P may not be deliverable and instead need to be pre-incorporated into a lipid bilayer to study their transport properties. We therefore decided to investigate the use of acridinone as a scaffold for a bis-urea and thiourea-based anion transporters. Acridinones are aromatic heterocyclic compounds that exhibit distinct optical properties, resulting from strong absorption and emission in the UV-vis region. These compounds (1-10) possess a potential additional hydrogen bond donor (as with carbazole bis-ureas) ${ }^{10}$ from the acridinone $\mathrm{NH}$ group whilst the lipophilicity of the compounds is attenuated by the heteroatoms relative to analogous acridine-based compounds (Figure 1).

We have previously studied acridinones as anion receptors and sensors. ${ }^{11}$ Compounds $\mathbf{1}$ and $\mathbf{6}$ were found to interact with chloride. Perturbations in the chemical shifts attributed to the (thio)urea protons were fit to a 1:1 receptor:anion binding model and chloride binding constants were determined to be $K_{\mathrm{a}}$ $=273 \mathrm{M}^{-1}$ and $K_{\mathrm{a}}=53 \mathrm{M}^{-1}$ for the bis-urea (1) and bis-thiourea

a. School of Chemistry (F11), The University of Sydney, NSW 2006, Australia.

b. The University of Sydney nano Institute (SydneyNano), The University of Sydney, NSW 2006, Australia.

+ Dedicated to friend and colleague Professor Hiroyuki Furuta on the occasion of his 65th Birthday.

Electronic Supplementary Information (ESI) available: synthesis and characterisation details, anion binding and transport studies and $\mathrm{X}$-ray crystallography. See DOI: 10.1039/x0xx00000x
(6), respectively. In this study we prepared a larger series of bisureas and thio-ureas and studied their anion transport properties in phospholipid bilayer membranes.

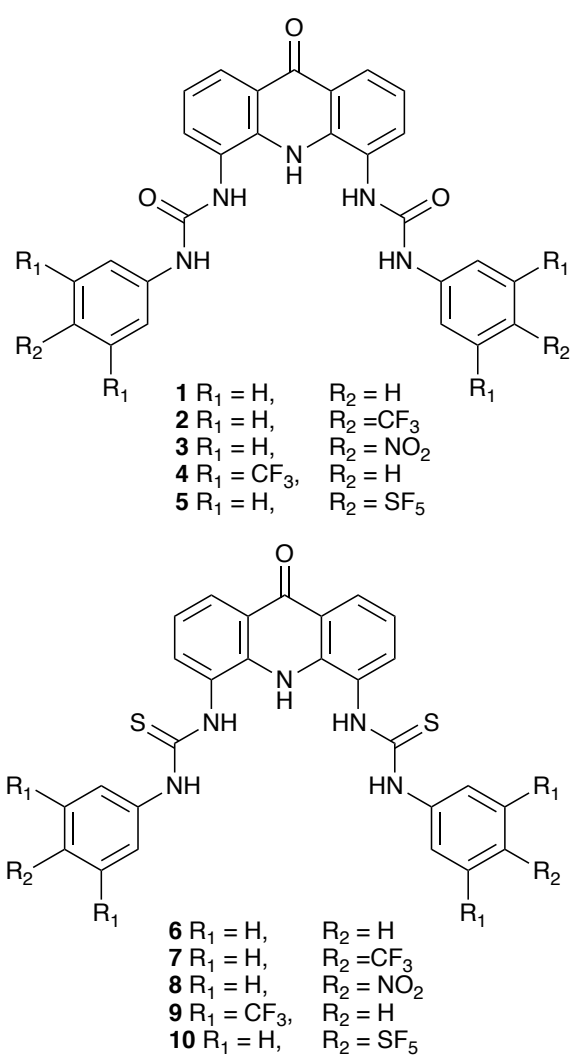

Figure 1 The structures of ureas 1-5 and thio-ureas 6-10.

\section{Results and discussion}

Synthesis 
The acridinone series was synthesised via a four-step synthetic pathway. Initially, 1,9-diaminoacridinone was prepared following the method reported by García-Garrido et al., ${ }^{11}$ with alterations made to the method of nitro group reduction. A Jourdan-Ullman condensation reaction between commercially available 2-bromo-3-nitrobenzoic acid and 2-nitroaniline was performed to afford compound $\mathbf{1 1}$ (Scheme 1). ${ }^{12}$ Copper powder was used as a catalyst in this reaction, which is performed under molten conditions at $190^{\circ} \mathrm{C}$ for $4 \mathrm{~h}$. The high temperatures required for the reaction are a consequence of the significant deactivation of the bromine position in 2-bromo3-nitrobenzoic acid. This deactivation was reflected in the poor yields achieved for this step, which did not exceed $30 \%$. Ring closure of the intermediate was initiated by dissolving $\mathbf{1 1}$ in conc. $\mathrm{H}_{2} \mathrm{SO}_{4}$ and heating to $100{ }^{\circ} \mathrm{C}$ for $1 \mathrm{~h}$ to afford the $1,9-$ dinitroacridinone intermediate $\mathbf{1 2}$ in $79 \%$ yield.<smiles>Nc1ccccc1[N+](=O)[O-]</smiles>

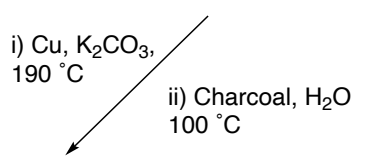<smiles>O=C(O)c1cccc([N+](=O)[O-])c1Nc1ccccc1[N+](=O)[O-]</smiles>

$11(30 \%)$

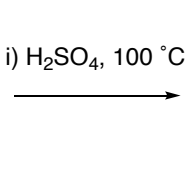

precursor 12<smiles>O=c1c2cccc([N+](=O)[O-])c2[nH]c2c([N+](=O)[O-])cccc12</smiles>

$12(79 \%)$
Scheme 1 Synthesis of precursor 12

Palladium on carbon was used to catalyse the reduction of compound 12 in DMF. The solution was filtered through celite to remove the palladium on carbon, followed by removal of DMF in vacuo to afford bis-amine $\mathbf{1 3}$ in $94 \%$ yield.

The synthesis of compounds 1-4 and 6-9 was initially attempted by reacting 12 with an excess of the respective isocyanate or isothiocyanate in a minimum amount of dry DMF and the progress was followed by TLC. Upon completion, the reaction mixture was poured into ice water, resulting in precipitation of the desired product and other side products. Residual DMF was removed with additional washes of deionised water and the side products were removed with washes of various non-polar solvent mixtures (see the experimental section for details). DMSO was found to be a suitable alternative solvent and was used in several the iso(thio)cyanate condensation reactions.

4-(Pentafluorosulfanyl)phenyl isocyanate and isothiocyanate and were prepared from 4-pentafluorosulfanylaniline. The isothiocyanate was formed by reacting the aniline with thiophosgene in a biphasic mixture of dichloromethane and sat. $\mathrm{NaHCO}_{3(\text { aq) }}$ solution, at room temperature. The two phases were separated before the DCM was removed in vacuo. The desired 4-(pentafluorosulfanyl)phenyl isothiocyanate product was used without further purification to prevent potential hydrolysation of decomposition and added to a DMSO solution of 13. Compound $\mathbf{1 0}$ was afforded in a $33 \%$ yield. To prepare compound 5, 4-pentafluorosulfanyl aniline and a small excess of triphosgene were dissolved in toluene and heated to $70{ }^{\circ} \mathrm{C} . .^{13}$ Triethylamine (TEA) was added immediately to neutralise $\mathrm{HCl}$ forming in the reaction. After work-up, a solution of $\mathbf{1 3}$ in DMF was added dropwise to the solution of 4(pentafluorosulfanyl)phenylisocyanate in toluene to afford $\mathbf{5}$ in $63 \%$ yield.

\section{X-ray crystallography}

Crystals of $\mathbf{3}$ of suitable quality for analysis using single X-ray crystal diffraction were obtained by slow evaporation of a saturated DMSO solution (CCDC 2101004). Compound 3 crystallises in the space group $P 2_{1} / n$ with one formula unit in the asymmetric unit and two DMSO solvents of crystallisation. Close intramolecular hydrogen bonds cause one of the urea groups to be positioned inwards to the centre of the molecule. This orientation allows for hydrogen bonding between the $\mathrm{O} 3$ urea carbonyl acceptor and the acridinone N4 donor group (N4…03: 2.736(4) $\AA$ ), and between $\mathrm{O} 3$ and the phenyl C5 donor (C5‥03: 2.867 (4) $\AA$ ). This close hydrogen bonding is also observed for the urea carbonyl O5 (C25‥05: 2.896 (4) Å). Close hydrogen bonds also exist for one DMSO molecule with the outwardly facing urea, forming a $\mathrm{R} 1 \frac{2}{2} 6$ motif between $\mathrm{N}-\mathrm{H}$ donor

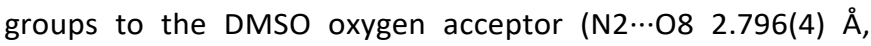

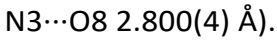

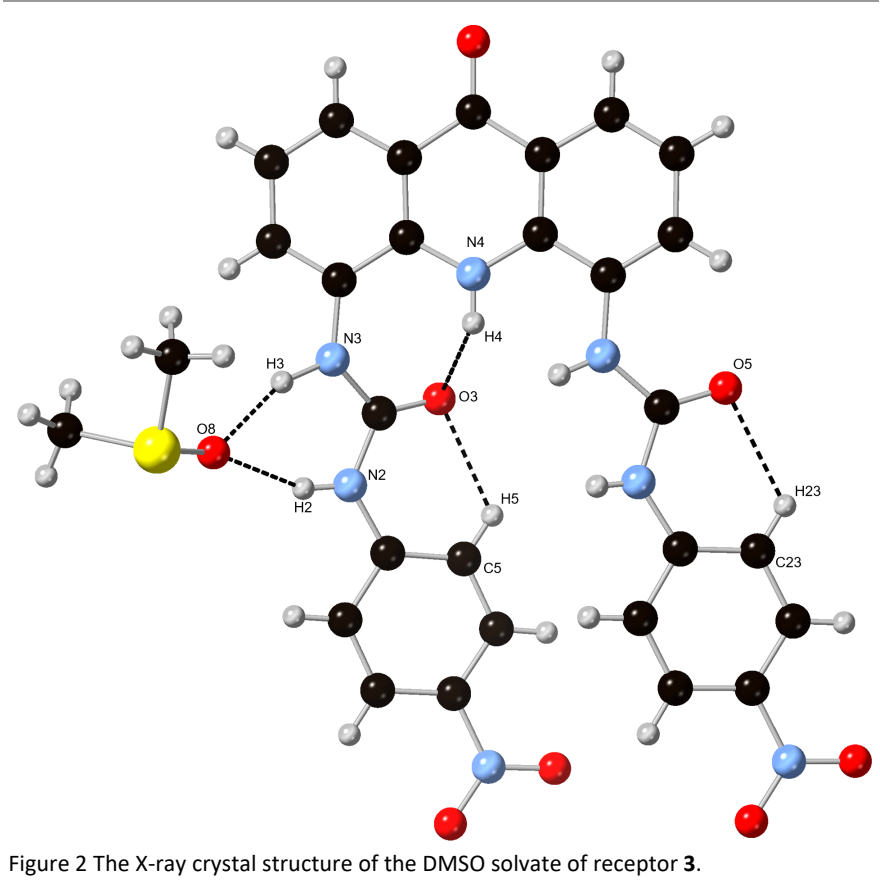




\section{Anion binding studies}

Proton NMR titrations were conducted with compounds $\mathbf{1}$ - 10 in DMSO- $d_{6} / 0.5 \% \mathrm{D}_{2} \mathrm{O}$ and tetrabutylammonium chloride (TBA $\mathrm{Cl})$. Solutions were titrated with up to 300 equivs. of TBACl. Large downfield shifts in the urea or thiourea $\mathrm{NH}$ resonances were observed upon addition of TBACl for all the compounds. Interestingly, the resonance attributed to the acridinone $\mathrm{N}-\mathrm{H}$ proton of bis-urea compounds 1-5 responded differently to the addition of $\mathrm{TBACl}$ compared to the corresponding resonance in the bis-thiourea compounds 6-10. Stacked plots of the titrations of each compound with TBACl are shown in the supplementary information. For titrations conducted with the bis-urea compounds the acridinone signal initially shifted slightly upfield, before reversing and moving downfield above approx. 10 equiv. of the TBACl. During the $\mathrm{Cl}^{-}$titrations of the bis-thiourea compounds, the acridinone $\mathrm{N}-\mathrm{H}$ proton resonance shifted downfield initially before plateauing at higher equivalents.

The change in chemical shift of the resonances for both (thio)urea protons and the acridinone $\mathrm{N}-\mathrm{H}$ proton upon addition of chloride were fitted to various binding models using the Bindfit applet. ${ }^{14,15}$ Fitting to a 1:1 receptor:guest binding model was found to result in a poor fit; however, fitting the data to a $1: 2$ receptor:guest binding model provided a significant improvement. Fcov ${ }_{\text {fit }}$ was calculated for each of the receptors and the covariance of fit of the 1:2 binding model was found to be 8 times greater than the $1: 1$ binding model for compound 6 , and at least 13 times greater for the other receptors. The reversal in direction of the acridinone $\mathrm{N}-\mathrm{H}$ proton resonance during titrations of the bis-urea species is additional evidence in support of a higher-order binding model. The fit complementarity suggests that two binding events occur over the course of the titration. The $K_{11}$ and $K_{12}$ binding constants for receptors $\mathbf{1 - 1 0}$ are displayed in Table 1.

Table 1 The stability constants $\left(\mathrm{M}^{-1}\right)$ for the complexation of receptors $1-10$ and $\mathrm{Cl}^{-}$(as TBA salt) in DMSO- $d_{6} / 0.5 \% \mathrm{D}_{2} \mathrm{O}$ at $298 \mathrm{~K}$.

\begin{tabular}{ccccc|} 
Compound & $K_{11^{a}}{ }^{a}$ & $K_{12}{ }^{\mathrm{a}}$ & $\alpha^{\mathrm{b}}$ & $\mathrm{F} \mathrm{coV}_{\text {fit }}{ }^{\mathrm{c}}$ \\
\hline $\mathbf{1}$ & 247 & $-\mathrm{e}$ & $-\mathrm{e}$ & 13 \\
$\mathbf{2}$ & 264 & 1.3 & 0.005 & 90 \\
$\mathbf{3}$ & 500 & 2 & 0.004 & 158 \\
$\mathbf{4}$ & 357 & 3.9 & 0.01 & 92 \\
$\mathbf{5}$ & 328 & 1.7 & 0.005 & 386 \\
$\mathbf{6}$ & 115 & 2.4 & 0.02 & 8 \\
$\mathbf{7}$ & 121 & 2 & 0.02 & 53 \\
$\mathbf{8}$ & 241 & 3.7 & 0.02 & 48 \\
$\mathbf{9}$ & 183 & 3.3 & 0.02 & 31 \\
$\mathbf{1 0}$ & 136 & 3.3 & 0.02 & 22
\end{tabular}

${ }^{a}$ All errors $<5 \%$. ${ }^{b}$ The interaction parameter $(\alpha)$ calculated by multiplying $K_{21}$ by 4 and dividing by $K_{11}$; a value of $\alpha<1$ is indicative of negative cooperativity. ${ }^{\mathrm{c}}$ Factor of covariance of fit $\left(\mathrm{Fcov}_{\mathrm{fit}}\right.$ ) calculated by dividing $\operatorname{cov}_{\text {fit }} 1: 2$ with $\operatorname{cov}_{\text {fit }} 1: 1$; a value greater than 5 indicates a 1:2 binding model is favoured. ${ }^{15}$ e $K_{12}$ value for compound 1 was extremely small.

A potential explanation the contrasting shifts of the acridinone $\mathrm{NH}$ proton resonances of the urea and thiourea compounds upon addition of chloride could be the tautomerism of the acridinone group. Previously, we elucidated the solid-state structure of the chloride complex of compound $\mathbf{1}$ and found it crystallised as the hydroxy tautomer (CCDC 629282). ${ }^{11} \mathrm{~A}$ chloride anion was bound by the protons of the two urea groups, and a second chloride was stabilised by a hydrogenbonding interaction with the hydroxy $\mathrm{O}-\mathrm{H}$ donor group.

After examination of the ${ }^{13} \mathrm{C}-\mathrm{NMR}$ spectra of compounds 1-10, the formation of the alternate tautomer could be discounted. Each ${ }^{13} \mathrm{C}-\mathrm{NMR}$ spectrum contains a resonance between 176.8-177.4 ppm, which is a fingerprint resonance for the C9 carbon of acridinone in DMSO- $d_{6}$. This characteristic resonance is present in numerous acridinone systems reported in the literature, ${ }^{16,17}$ including in systems locked in the acridinone form via $\mathrm{N}$-substitution. ${ }^{18-20}$ In addition, physicochemical studies and theoretical calculations on similar acridinone molecules have confirmed the hydroxyacridine tautomer is not present at equilibrium in DMSO solutions. ${ }^{16,21,22} \mathrm{~A}$ permanent tautomeric switch from the acridinone to the hydroxyacridine form of the system would result in a significant change in the C9 carbon environment, and the ${ }^{13} \mathrm{C}-\mathrm{NMR}$ resonance for this carbon in acridine systems is more typically found in the range 140-160 ppm. ${ }^{23}$

Furthermore, the occurrence of tautomerism over the course of the ${ }^{1} \mathrm{H}-\mathrm{NMR}$ titrations is unlikely as the signal attributed to the acridinone $\mathrm{NH}$ proton resonance remains sharp and can be followed continuously for each titration. However, the appearance of new resonances upon addition of multiple (up to 300 ) equivalents of chloride during the ${ }^{1} \mathrm{H}-\mathrm{NMR}$ titrations of compounds 1-5 is evidence in support of tautomerism of the chloride complex that is slow on the NMR timescale. Specifically, the appearance of a new peak at $11.56 \mathrm{ppm}$ in the spectrum of $\mathbf{1 0}$ after the addition of 300 equivs. of TBACl (Figure S91) may be attributed to the $\mathrm{OH}$ proton of the hydroxyacridine species.

The shift in the bis-urea acridinone NH proton resonance and evidence of a 1:2 receptor:guest binding process can be rationalised by considering that an intramolecular hydrogen bond may form in the free receptor when the urea carbonyl is orientated inwards (Scheme 2a, top structure), akin to the solidstate structure of compound $\mathbf{3}$ (Figure 2). The same intramolecular hydrogen bond may not be possible in the bisthiourea compounds $\mathbf{6 - 1 0}$ because the bulk of the sulfur atom means the thiourea cannot flip inwards as effectively and sulfur is a poorer hydrogen bond acceptor than oxygen (Scheme $2 \mathrm{~b}$ ). Therefore, the ${ }^{1} \mathrm{H}-\mathrm{NMR}$ signal attributed to the acridinone $\mathrm{NH}$ proton is shifted further downfield for the bis-urea compounds compared to the bis-thiourea compounds due to deshielding of the proton caused by the intramolecular hydrogen bond.

At low equivalents of $\mathrm{TBACl}$, a 1:1 receptor:guest complex is preferred where the urea carbonyl group flips back to the exterior of the molecule and chloride is bound through $\mathrm{N}-\mathrm{H}$ hydrogen bonds within the central cavity (Scheme 2a, middle structure). This binding event induces a downfield shift in the signals of the urea protons, which form cooperative hydrogen bonds with chloride, and an upfield shift in the acridinone $\mathrm{N}-\mathrm{H}$ proton signal due to disruption of the intramolecular hydrogen bond formed with the urea carbonyl oxygen (presumably the 
hydrogen bond to chloride is less deshielding than the intramolecular interaction with the carbonyl oxygen). At higher host/guest ratios, the equilibrium shifts to a 1:2 receptor:guest complex via another conformational switch. This time both urea carbonyl groups flip inwards, and each bind a chloride anion through $\mathrm{N}-\mathrm{H}$ hydrogen bonds on the exo-face of the complex (Scheme 2 a bottom most structure). The acridinone $\mathrm{N}-\mathrm{H}$ proton resonance begins to shift back downfield due to the reformation of intramolecular hydrogen bonding interactions with the urea carbonyl oxygens. A similar conformational change was proposed for the binding modes of carbazole-based bis-ureas and bis-thioureas. ${ }^{10}$

The thiourea groups of compounds $\mathbf{6 - 1 0}$ are initially held closer to perpendicular to the acridinone motif (Scheme $2 b$, top structure), in a manner similar to the ground state computational studies performed by Dias et al. on their anthracene-based thiourea compounds. ${ }^{7}$ At lower equivalents of $\mathrm{TBACl}$, a 1:1 receptor:guest complex is preferred with a chloride anion held within the central cavity (Scheme $2 b$, middle structure). Hydrogen bonding interactions between chloride and all thiourea $\mathrm{N}-\mathrm{H}$ protons and the acridinone $\mathrm{N}-\mathrm{H}$ proton cause the ${ }^{1} \mathrm{H}-\mathrm{NMR}$ resonances for these protons to collectively shift downfield. At higher equivalents of guest, each thiourea group binds a chloride anion individually as the equilibrium shifts towards a 1:2 receptor:guest complex (Scheme 2b, bottom most structure). The bulky nature of the sulfur atoms means the thiourea groups are oriented perpendicular to the acridinone motif. An intramolecular bonding interaction does not form between the thiourea sulfur atoms and the acridinone $\mathrm{N}-\mathrm{H}$ proton due to the steric bulk and poorer hydrogen bond acceptor ability of sulfur, and hence the signal attributed to the acridinone $\mathrm{N}-\mathrm{H}$ proton begins to plateau. The acridinone $\mathrm{N}-\mathrm{H}$ resonance should in fact move upfield, but the minimal shift experienced by this signal reflects the small amount of 1:2 complex that forms.

The interaction parameter, $\alpha$ (Table 1), was calculated for receptors 1-10 and found to be less than 1 in each case, 15 indicating that the 1:1 complex is heavily favoured over the 1:2 complex (negative cooperativity). ${ }^{24}$ This, in concurrence with the proposed binding modes presented in Scheme 2, suggests a cooperative binding site featuring multiple hydrogen bonding interactions encapsulating chloride is present in the 1:1 binding complex. The shift to a $1: 2$ binding complex removes this cooperativity, as reflected in the much smaller $K_{12}$ values compared to $K_{11}$ values for the acridinone series.

An assessment of the $K_{11}$ values suggests that the bis-urea compounds exhibit a higher affinity towards chloride than their bis-thiourea analogues, despite the enhanced acidity of the thiourea protons. The higher binding affinity can be attributed to the planarity in the molecule necessary for optimal binding in the 1:1 complex. The smaller oxygen atoms of the bis-urea receptors are more capable of achieving the required planarity than the bulky thiourea sulfur atoms, which distort the shape of the binding site. A similar phenomenon was observed for bis(thio)urea based receptors. 7,10

The trend in $K_{11}$ values for both series of receptors is in agreement with the expected trend when increasingly electron- withdrawing substituents are appended to the peripheral phenyl rings. The parent phenyl receptors 1 and $\mathbf{6}$ exhibit the lowest affinities for chloride. The $K_{11}$ values for receptors $\mathbf{2}$ and 7 are smaller than the $K_{11}$ values for 5 and 10, respectively, highlighting the enhanced electron-withdrawing ability of the para- $\mathrm{SF}_{5}$ group compared to a para- $\mathrm{CF}_{3}$ group. The para- $\mathrm{NO}_{2}(3$ and 8 ) and 3,5-bis- $\mathrm{CF}_{3}$ (4 and 9) derivatives displayed the highest affinities for chloride, which is consistent with the increased acidity of their (thio)urea protons, induced by the strong electron-withdrawing nature of these substituents.

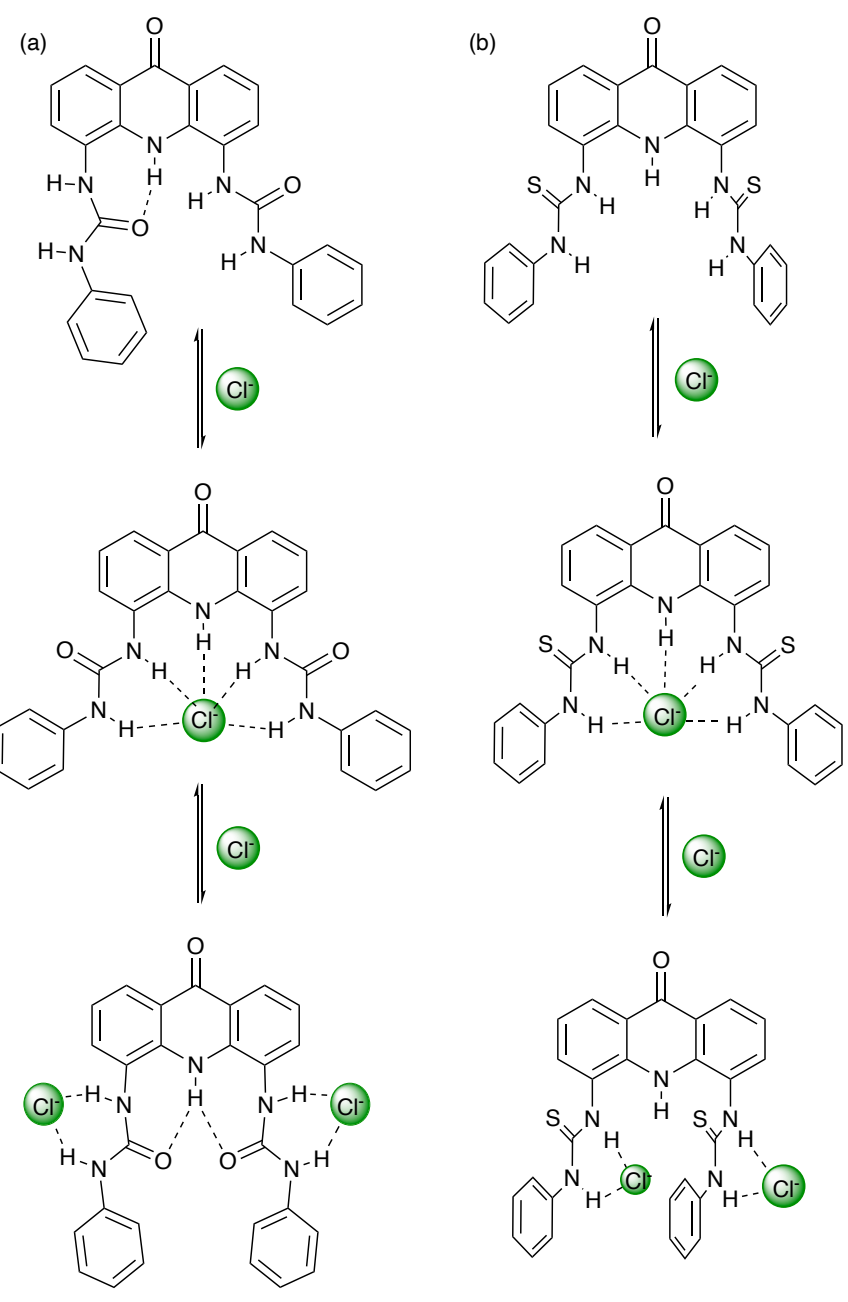

Scheme 2 The general schematic of the proposed binding modes of the bis-urea receptors (a) 1-5 and (b) thioureas 6 - 10. Hydrogen-bonding interactions are depicted as dashed lines.

\section{Anion transport studies}

\section{Chloride/nitrate exchange assay}

The anion transport activity of acridinone-based bis-(thio)urea receptors 1-10 was investigated using the $\mathrm{Cl}-/ \mathrm{NO}_{3}{ }^{-}$exchange assay (Figure 3). ${ }^{25}$ Large unilamellar vesicles (200 $\mathrm{nm}$ ) were prepared with a $\mathrm{NaCl}$ internal solution $(487 \mathrm{mM})$ buffered to $\mathrm{pH}$ 7.2 with sodium phosphate salts $(5 \mathrm{mM})$. The vesicles were subsequently suspended in a $\mathrm{NaNO}_{3}$ external solution ( $487 \mathrm{mM}$ ) buffered to $\mathrm{pH} 7.2$ following a similar method. Receptors were 
added as a DMSO solution ( $10 \mu \mathrm{L}$ to a vesicle suspension of 5 $\mathrm{mL}$ ) at $\mathrm{t}=0 \mathrm{~s}$, and chloride efflux was measured using a chloride ion-selective electrode (ISE). Experiments were conducted for $300 \mathrm{~s}$ before detergent was added to the vesicles providing the $100 \% \mathrm{Cl}^{-}$efflux reading, which was used for calibration of the results. Dose response studies were performed followed by Hill analysis of $\mathrm{Cl}^{-}$efflux at $270 \mathrm{~s}$ to quantify transport activity.

Dose response studies of compounds 1, 2, $\mathbf{6}$ and $\mathbf{7}$ could not be completed due to the insolubility of the receptors in aqueous solution at the required concentrations. These compounds proved less active than the other receptors tested, and addition as a DMSO solution at concentrations of $0.5 \mathrm{~mol} \%$ or higher resulted in precipitation of the receptors. Solubility issues were also found with the para-SF 5 receptors 5 and $\mathbf{1 0}$. The receptors both reached a maximum of $75 \%$ efflux ( $270 \mathrm{~s}$ ) at the highest concentration tested, and convergence in the chloride efflux curves at higher transporter loadings was observed. These findings suggest that receptor $\mathbf{5}$ reaches its solubility limit at around $0.1 \mathrm{~mol} \%$, and 10 at closer to $1 \mathrm{~mol} \%$. However, as the final efflux is above $50 \%$, an $\mathrm{EC}_{50}$ value could still be reliably calculated for these compounds. The calculated $\mathrm{EC}_{50}$ values, which represent the concentration required to facilitate $50 \%$ transport, and Hill coefficients, which provide an indication of the stoichiometry required for the transport process, are shown in Table 2. Efflux plots and fitting to the Hill equation for each compound are available in the supplementary information.

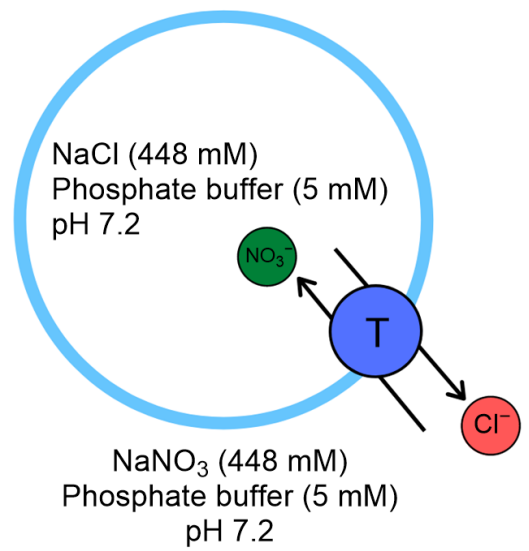

Figure 3 Schematic of the $\mathrm{Cl}^{-} / \mathrm{NO}_{3}{ }^{-}$exchange assay, monitored by chloride-ISE. POPC vesicles were loaded with phosphate $(5 \mathrm{mM})$ buffered $\mathrm{NaCl}(448 \mathrm{mM})$ and then suspended in phosphate $(5 \mathrm{mM})$ buffered $\mathrm{NaNO}_{3}(448 \mathrm{mM})$ and adjusted to $\mathrm{pH} 7.2$.
Table 2. $\mathrm{EC}_{50}$ values and Hill coefficients ( $\mathrm{n}$ ) from the $\mathrm{Cl}-/ \mathrm{NO}_{3}{ }^{-}$exchange assay, maximum transport rate at a $0.05 \mathrm{~mol} \%$ loading of the transporter, and calculated lipophilicity values $(\operatorname{clog} P)$ are displayed for the transporters.

\begin{tabular}{ccccc}
\hline Compound & $\mathrm{EC}_{50}(\mathbf{m o l} \%)^{\mathrm{a}}$ & $\mathbf{n}$ & Maximum rate $\left(\mathbf{\% ~ s}^{-1}\right)^{\mathbf{b}}$ & $\operatorname{clog} \boldsymbol{P} \mathbf{c}$ \\
\hline $\mathbf{3}$ & 0.0011 & 1.3 & $21.9^{\mathrm{d}}$ & 3.96 \\
$\mathbf{4}$ & 0.0068 & 1.0 & 1.01 & 6.41 \\
$\mathbf{5}$ & 0.025 & 3.1 & $0.27^{\mathrm{e}}$ & $-\mathrm{f}$ \\
\hline $\mathbf{8}$ & 0.042 & 3.0 & 0.56 & 4.73 \\
$\mathbf{9}$ & 0.064 & 2.6 & 0.28 & 7.08 \\
$\mathbf{1 0}$ & 0.14 & 2.0 & $0.07^{\mathrm{e}}$ & $-\mathrm{f}$
\end{tabular}

${ }^{a} \mathrm{EC}_{50}$ at $270 \mathrm{~s}$, shown as receptor:lipid molar percent. ${ }^{\mathrm{b}}$ Maximum initial rate calculated at a loading of $0.05 \mathrm{~mol} \%$, by fitting efflux plot to an exponential decay function. " Average clog $P$ values calculated using VCCLab. ${ }^{26,27}$ d Initial rate

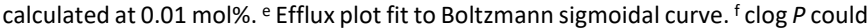
not be reliably calculated.

Bis-urea compounds 3-5 were found to be considerably more active than their thiourea analogues 8-10, in contrast to trends previously observed for many families of anionophores. ${ }^{28-30}$ Typically, sulfur atoms enhance the acidity of the thiourea $\mathrm{NH}$ protons relative to the urea oxygen atoms, which leads to stronger coordination of a chloride anion and enhanced lipophilicity, allowing more efficient diffusion from the water/membrane interface. The $\mathrm{EC}_{50}$ values can again be rationalised by considering the planarity afforded in the 1:1 binding mode of the bis-urea compounds (molecular modelling can be viewed in the supplementary information, Figure S149). The planar conformation offers a more complete encapsulation of a bound chloride anion and better shielding of the negative charge from the polar head groups of the lipid bilayer. Additionally, the bis-urea oxygens are held almost parallel to the acridinone plane due to the presence of intramolecular hydrogen bonds. The 1:1 binding mode of the thioureas is distorted due to the bulk of the sulfur atoms (Figure S150). The bound chloride anion is more exposed to the external environment, and the bis-thiourea sulfur atoms sit almost perpendicular to the acridinone plane. The sulfur atoms are also exposed to the polar phospholipid head groups and the nonpolar bilayer interior, making transport less efficient. A similar conformation was observed for the anthracene-based bis(thio)urea transporters which was attributed to the instability of the thiourea compounds in solution. ${ }^{7}$ The acridinone bisthiourea compounds in DMSO solution were found to slowly decompose but this does not happen on the time scale of the transport experiments. The potential for tautomerism of the bis-urea receptors to occur during the transport process cannot be discounted.

The beneficial effect of strongly electron-withdrawing groups on transport activity is apparent for both the bis-urea and bisthiourea series of receptors. para- $\mathrm{NO}_{2}$ and $3,5-\mathrm{CF}_{3}$ groups increased the binding affinity of the (thio)urea groups towards chloride, shown in Table 1 and also facilitate a greater degree of delocalisation of the negative charge around the molecule, thereby enhancing the lipophilicity of the receptor:guest complex. ${ }^{31}$ Compounds $\mathbf{3}$ and $\mathbf{4}$ are highly effective chloride transporters. The $E_{50}$ value calculated for compound $\mathbf{3}$ of 0.0011 mol\% ranks it among the most effective transporters reported by our group. For comparison, the most potent ortho- 
phenylenediamine-based transporter has a $\mathrm{EC}_{50}$ value of 0.0015 mol\% in the $\mathrm{Cl}^{-} / \mathrm{NO}_{3}{ }^{-}$exchange assay. ${ }^{32}$ Measurable activity was observed for compound $\mathbf{3}$ at transporter to lipid loadings as low as 1:500000 transporter:lipid ratio (2 $\mathrm{nM}$ in the aqueous suspension, or 0.0002 mol\%), as shown in Figure 4.

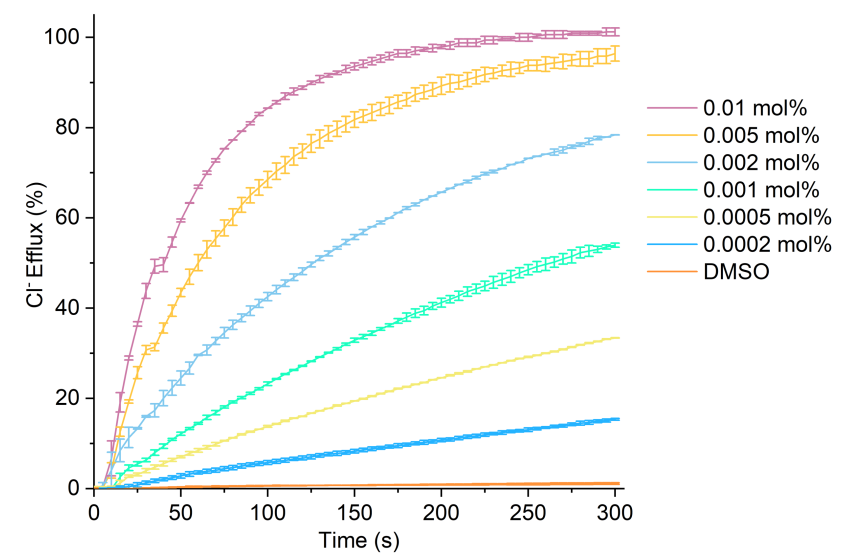

Figure 4. Dose response studies for compound 3 using the $\mathrm{Cl}^{-} / \mathrm{NO}_{3}{ }^{-}$ISE assay. Each data point is the average of two repeats with error bars to show standard deviation. A run of pure DMSO was used as a control.

A Hill coefficient of close to $\mathrm{n}=1$ was determined for receptors 3 and 4, indicating that these compounds transport $\mathrm{Cl}^{-}$in a 1:1 host:guest stoichiometry. The Hill coefficient for the other compounds $(\mathbf{5}, \mathbf{8}-\mathbf{1 0})$ was determined to be $n \geq 2$, suggesting a higher stoichiometry is required to facilitate transport. The distorted binding site present in bis-thiourea compounds 8-10 may leave a bound chloride anion too exposed to the lipid bilayer interior. A requirement of at least two bis-thiourea molecules to successfully shield the negative charge is another potential explanation for the poorer transport activity displayed by the bis-thiourea compounds in this assay compared to their bis-urea analogues.

The rates of chloride efflux achieved by receptors 4, 5 and 8-10 were calculated from the efflux plots at a transporter loading of $0.05 \mathrm{~mol} \%$, to offer comparison across the series, and are shown in Table 2. The high activity of compound $\mathbf{3}$ in the $\mathrm{Cl}-/ \mathrm{NO}_{3}{ }^{-}$exchange assay allowed the determination of the maximum transport rate to be calculated at a lower transporter loading of $0.01 \mathrm{~mol} \%$. The transport rate values of compounds 3-4 and 8-9 were obtained by fitting the respective efflux plots to an exponential decay function and calculating the initial rate. The trend in rates for these compounds is concordant with the calculated $\mathrm{EC}_{50}$ values, and the rate of transport facilitated by compound $\mathbf{3}$ was significantly higher than the other compounds tested even at a lower loading. The efflux plots at $0.05 \mathrm{~mol} \%$ loading of the para-SF 5 compounds $\mathbf{5}$ and $\mathbf{1 0}$ were sigmoidal in shape and were therefore fit to a Boltzmann sigmoidal curve. The maximum rate of transport calculated for these compounds occurs in the middle of the experiment, rather than at the beginning. The slow initial rate of transport exhibited by the para-SF 5 receptors is reflective of their poor solubility, suggesting that delivery of the transporter and its partition into the lipid bilayer may be the rate-limiting step of the transport process.

The degree of lipophilicity of compounds 3-4 and 8-9 was quantified by calculating the octanol-water partition coefficients ( $\operatorname{cog} P$ ) using the online VCCLab ALOGPS2.1 applet, ${ }^{26}$ and the values are displayed in Table 2 . The clog $P$ values of para-SF 5 derivatives $\mathbf{5}$ and $\mathbf{1 0}$ could not be accurately calculated using the online VCCLab applet; however, it is reported extensively in the literature that these groups are more lipophilic than para- $\mathrm{CF}_{3}$ compounds. ${ }^{33,34}$ Previous research by the our group and others has demonstrated that lipophilicity is a crucial parameter dictating the transport activity of synthetic mobile carriers. ${ }^{35-37}$ Systems that are too lipophilic cannot diffuse into the aqueous phase or pass through the barrier formed by the polar head groups, which is necessary to extract or release of an anion into the aqueous bulk. This can become the rate-limiting step of the transport process. The greater lipophilicity of bis- $\mathrm{CF}_{3}$ receptor 4 (clog $P=6.41$ ) could potentially slow its transport rate compared to compound $\mathbf{3}$, which has a more moderate degree of lipophilicity (clog $P=$ 3.96).

\section{Cationophore coupled transport assay}

The mechanism of the chloride transport processes mediated by anionophores 3-5 and 8-10 were investigated using complementary cationophore coupled assays (Figure 5). POPC vesicles were loaded with $300 \mathrm{mM} \mathrm{KCl}$ and suspended in a 300 $\mathrm{mM}$ solution of either potassium gluconate (KGlc) or $\mathrm{KNO}_{3}$, buffered to $\mathrm{pH} 7.20$ with potassium phosphate salts. Gluconate cannot be transported across the bilayer because it is large and polar; thus, compound-mediated $\mathrm{Cl}^{-}$transport is dependent on coupling to either valinomycin or monensin. Both cationophores transport $\mathrm{K}^{+}$across the bilayer via different mechanisms and indicate different modes of $\mathrm{Cl}^{-}$transport.

Valinomycin strictly uniports $\mathrm{K}^{+}$, thus coupling to valinomycin indicates electrogenic transport of $\mathrm{Cl}^{-}$facilitated by the tested transporter. In contrast to valinomycin, monensin exchanges $\mathrm{K}^{+}$and $\mathrm{H}^{+}$across the phospholipid bilayer, thus coupling to monensin is indicative of the electroneutral symport of $\mathrm{Cl}^{-} / \mathrm{H}^{+}$out of the vesicle facilitated by the anion transporter.

Receptors were added as a DMSO solution $(10 \mu \mathrm{L})$ at $t=0$ and efflux of chloride was measured using a $\mathrm{Cl}^{-}$ion-selective electrode. Detergent was added at $t=300 \mathrm{~s}$ to lyse the vesicle and provide a reading for $100 \% \mathrm{Cl}^{-}$efflux. Transport activity in $\mathrm{KNO}_{3}$ external solution should correspond to the results of the $\mathrm{Cl}-/ \mathrm{NO}_{3}{ }^{-}$exchange assay, whereas activity in KGlu external solution should be significantly reduced.

Experiments with a KGlc external solution were repeated in the presence of valinomycin and monensin, separately. The cationophores were added at $t=-30 \mathrm{~s}$ as a DMSO solution (10 $\mu \mathrm{L}, 0.1$ mol\% loadings, with respect to lipid concentration), before transporters were added as a DMSO solution $(10 \mu \mathrm{L})$ at $t$ $=0 \mathrm{~s}$. The transporter loading for each receptor was chosen to closely match the respective $\mathrm{EC}_{50}$ value calculated for the $\mathrm{Cl}-/ \mathrm{NO}_{3}{ }^{-}$exchange assay. 
a)

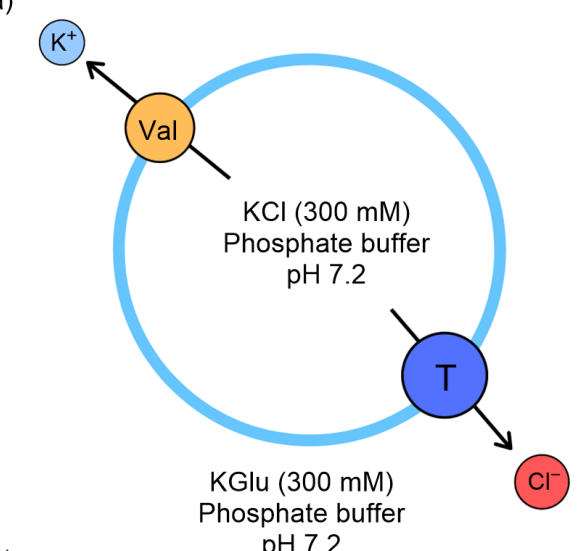

b)

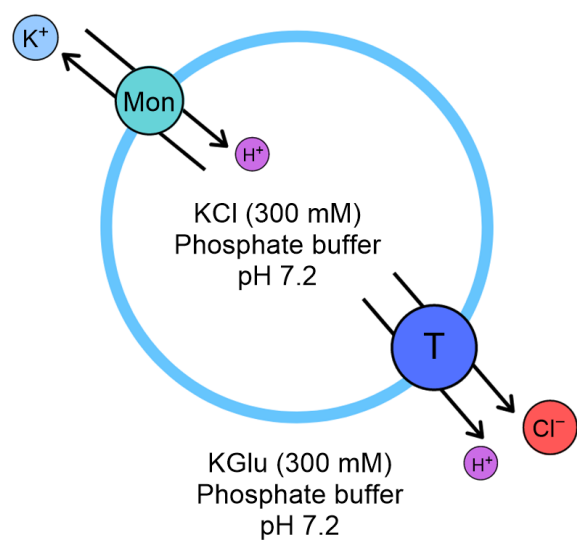

Figure 5 Schematic of the cationophore coupled $\mathrm{KCl}$ efflux assay, monitored by chlorideISE. POPC vesicles were loaded with phosphate buffered $\mathrm{KCl}(300 \mathrm{mM})$ and then suspended in phosphate buffered K-Glu $(300 \mathrm{mM})$ and adjusted to $\mathrm{pH} 7.2$. Diagrams show a) overall $\mathrm{KCl}$ efflux induced by valinomycin's (Val) electrogenic $\mathrm{K}^{+}$transport coupled to the anionophore's electrogenic $\mathrm{Cl}^{-}$transport resulting in an overall electroneutral $\mathrm{KCl}$ efflux and b) overall $\mathrm{KCl}$ efflux induced by monensin's (Mon) electroneutral $\mathrm{K}^{+} / \mathrm{H}^{+}$exchange and the transporter's $\mathrm{Cl}^{-} / \mathrm{H}^{+}$cotransport (or $\mathrm{Cl}^{-} / \mathrm{OH}^{-}$ exchange).

Chloride efflux in the presence of monensin was observed in all cases, and the results for receptors $\mathbf{4}$ and $\mathbf{9}$ are shown in Figure 6. In general, only minimal $\mathrm{Cl}^{-}$efflux was observed in the presence of valinomycin, indicating that the transporters do not function via an electrogenic $\mathrm{Cl}^{-}$uniport mechanism. The results in the presence of monensin demonstrate that the transporters function as $\mathrm{H}^{+} / \mathrm{Cl}^{-}$cotransporters. Compounds that facilitate a symport process have been shown to have potential for cancer treatment, by creating a $\mathrm{pH}$ gradient in tumour cells and inducing apoptosis. ${ }^{38-40}$

Compounds $\mathbf{9}$ and $\mathbf{1 0}$ were found to couple to valinomycin; however, efflux via this pathway was slower than when the compounds were coupled to monensin. Electrogenic $\mathrm{Cl}^{-}$ transport requires the transporter molecule to diffuse back across the lipid bilayer as a neutral species after release of a chloride anion. This can be inhibited if a neutral receptor interacts strongly with phosphate headgroups in the bilayer, making them unable to diffuse across the membrane. ${ }^{41,42}$ Initial investigations on compound $\mathbf{1}$ in 2007 highlighted the potential for strong interactions between the receptor and phosphate. ${ }^{11}$ It is likely that this interaction is the reason that compounds 3-5 and $\mathbf{8}$ are incapable of facilitating $\mathrm{Cl}^{-}$uniport. Compounds $\mathbf{9}$ and 10 have the lowest $\mathrm{Cl}^{-}$binding constants of the anionophores tested in the cationophore coupled assay (Table 1), and this suggests they likely also have the weakest affinity towards the headgroups. Therefore, compounds $\mathbf{9}$ and $\mathbf{1 0}$ can traverse the membrane as a neutral species and electrogenic $\mathrm{Cl}^{-}$transport is permitted; albeit at a slower rate than electroneutral $\mathrm{H}^{+} / \mathrm{Cl}^{-}$ cotransport.

(a)

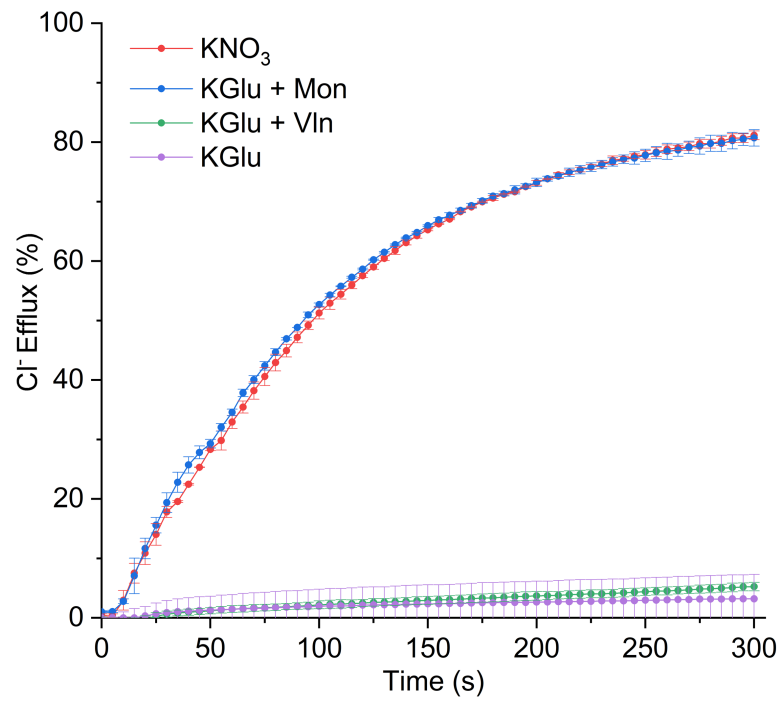

(b)

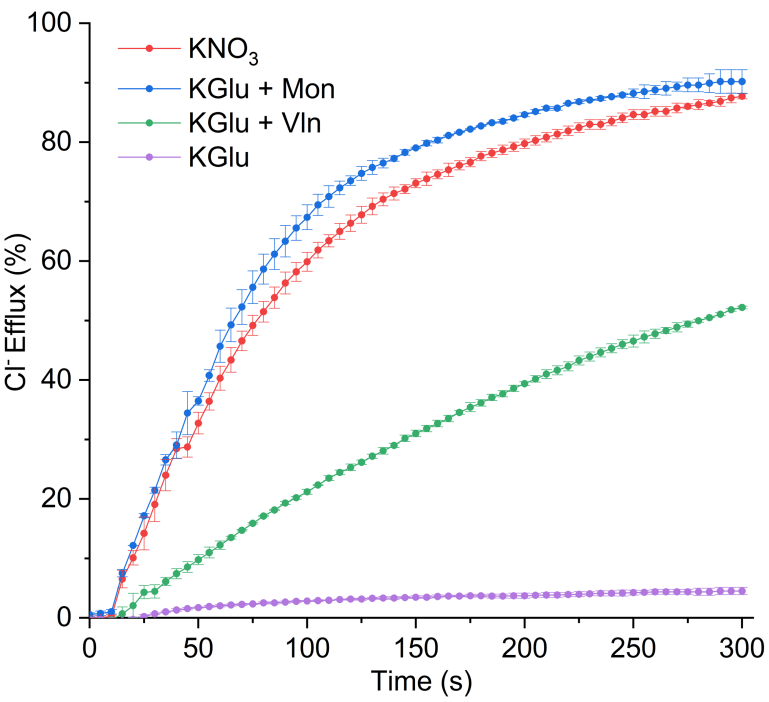

Figure 6. The chloride efflux facilitated by a) $\mathbf{4}(0.02 \mathrm{~mol} \%)$ and b) $\mathbf{9}(0.2 \mathrm{~mol} \%)$ in POPC vesicles loaded with $\mathrm{KCl}(300 \mathrm{mM})$ and suspended in an isotonic external solution containing $\mathrm{KNO}_{3}$ (red) or containing KGlu $(300 \mathrm{mM})$ in the presence of $0.1 \mathrm{~mol} \%$ monensin (blue) and $0.1 \mathrm{~mol} \%$ valinomycin (green). Each data point is the average of two repeats with the error bars showing the standard deviation. The chloride efflux from free transporter in the external KGlu solution is shown as the control (purple).

\section{HPTS assay for $\mathrm{HCl}$ transport}


The ability of compounds 3-5 and 8-10 to mediate electroneutral $\mathrm{H}^{+} / \mathrm{Cl}^{-}$cotransport was determined using HPTS fluorescence assays (Figure 7). Initially, dose response studies were performed, followed by Hill analysis, using a NMDG-Cl HPTS assay. ${ }^{43} \mathrm{~A}$ lower concentration of lipids are used in these experiments $(0.1 \mathrm{mM})$, meaning lower transporter concentrations are required to facilitate transport. $\mathrm{EC}_{50}$ values were calculated for the whole series of compounds 1-10 using this assay, offering a more complete picture of transport activity.

Vesicles $(200 \mathrm{~nm})$ were prepared with an internal solution of NMDG-Cl (100 mM), buffered with HEPES ( $5 \mathrm{mM})$ to $\mathrm{pH} 7.0$, and containing HPTS ( $1 \mathrm{mM})$. The LUVs were then suspended in the same external solution of NMDG-Cl which had not been treated with HPTS. An artificial $\mathrm{pH}$ gradient was initiated for each experiment using a base pulse of NMDG $(5 \mathrm{mM})$, before the transporter was added to the suspension as a DMSO solution ( 5 $\mu \mathrm{L}$ to a total volume of $2.5 \mathrm{~mL}$ ) at $t=0 \mathrm{~s}$. $\mathrm{NMDG}^{+}$is a large, hydrophilic cation that cannot be transported through the bilayer; therefore, the only process possible capable of dissipating the $\mathrm{pH}$ gradient is $\mathrm{H}^{+} / \mathrm{Cl}^{-}$cotransport. Changes to the intravesicular $\mathrm{pH}$ induced by cotransport of $\mathrm{HCl}$ were followed by monitoring the change in fluorescence ratio of HPTS. Detergent was added at $t=210 \mathrm{~s}$ to lyse the vesicles and provide a calibration reading of $100 \%$ proton efflux. $\mathrm{EC}_{50}$ values and Hill coefficients for compounds $\mathbf{1 - 1 0}$ are displayed in Table 3.

Table 3. $\mathrm{EC}_{50}$ values and Hill coefficients ( $\mathrm{n}$ ) for compounds 1-10 in the NMDG-CI HPTS assay. $\mathrm{EC}_{50}$ values were calculated using the Hill equation.

$\begin{array}{cccc}\text { Compound } & \mathbf{E C}_{50}{ }^{\mathbf{a}} & \mathbf{n} & \mathbf{c l o g} \mathbf{P} \mathbf{b} \\ \mathbf{1} & 0.0077 & 1.2 & 3.72 \\ \mathbf{2} & 0.0035 & 0.9 & 5.45 \\ \mathbf{3} & 0.00015 & 0.8 & 3.96 \\ \mathbf{4} & 0.0076 & 0.5 & 6.41 \\ \mathbf{5} & 0.0055 & 1.1 & \mathrm{c} \\ \mathbf{6} & 0.15 & 1.2 & 4.34 \\ \mathbf{7} & 0.014 & 1.3 & 5.79 \\ \mathbf{8} & 0.0046 & 0.7 & 4.73 \\ \mathbf{9} & 0.036 & 0.9 & 7.08 \\ \mathbf{1 0} & 0.03 & 1.9 & \mathrm{c}\end{array}$

a $\mathrm{EC}_{50}$ at $t=180 \mathrm{~s}$, shown as receptor:lipid molar percent (mol\%). b Average clog $P$ values calculated using VCCLab. $26,27 \mathrm{c}$ clog $P$ could not be reliably calculated.

The transport activity of the bis-urea compounds 1-5 in this assay compared to the bis-thiourea compounds 6-10 mirrored the results of the $\mathrm{Cl}-/ \mathrm{NO}_{3}-$ ISE exchange assay. The calculated $\mathrm{EC}_{50}$ values for each of the bis-urea compound were at least 4 times smaller than their bis-thiourea analogues. Compound $\mathbf{3}$ was again the most potent transporter of the series, with an $\mathrm{EC}_{50}$ value of $0.00015 \mathrm{~mol} \%$, which is a factor of 10 smaller than the other anionophores tested, adding further evidence towards the effectiveness of the $\mathrm{NO}_{2}$ derivatives as anion transporters. Hill coefficients $(n)$ were close to $n=1$ in all cases aside from compound 10, where the value was closer to $n=2$. These findings indicate a 1:1 stoichiometry is preferred for transport under the conditions of this assay.
Interestingly, the para- $\mathrm{CF}_{3}$ compounds $\mathbf{2}$ and $\mathbf{7}$ were more active in the assay than the respective $3,5-\mathrm{bis}-\mathrm{CF}_{3}$ and para- $\mathrm{SF}_{5}$ derivatives. Aqueous solubility is less of an issue in these studies due to the lower concentrations required to facilitate transport, therefore it seems likely that lipophilicity plays a crucial role. The presence of two additional trifluoromethyl groups in receptors $\mathbf{4}$ and $\mathbf{9}$ greatly enhances the overall lipophilicity of the respective systems, and could result in unfavourable deliverability. A similar degree of lipophilicity is expected for para- $\mathrm{SF}_{5}$ derivatives $\mathbf{5}$ and $\mathbf{1 0}$, and the results suggest that these compounds also exceed the optimal degree of lipophilicity required for efficient chloride transport.

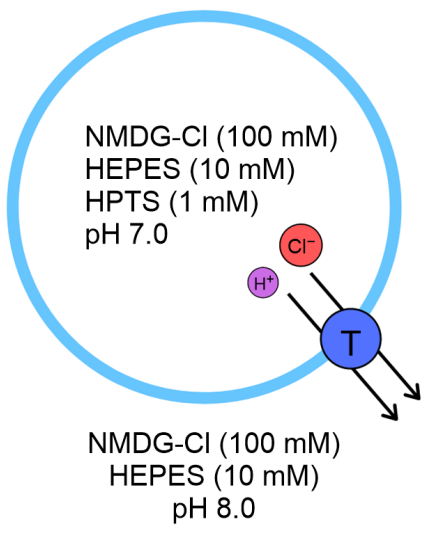

Figure 7 Schematic of the NMDG-Cl assay, monitored by HPTS fluorescence. POPC vesicles were loaded with HEPES (10 mM) buffered NMDG-Cl (100 mM) with HPTS (1 $\mathrm{mM})$ and suspended in HEPES (10 mM) buffered NMDG-Cl (100 mM) and adjusted to $\mathrm{pH}$ 7. To start the experiment a base pulse of NMDG $(0.5 \mathrm{M})$ was added to increase the external $\mathrm{pH}$ to $\mathrm{pH} 8$.

\section{Voltage dependent HPTS assay}

A voltage-dependent $\mathrm{KCl} \mathrm{HPTS}$ base pulse assay was employed to further probe the $\mathrm{H}^{+} / \mathrm{Cl}^{-}$symport mechanism facilitated by this class of anionophores (Figure 8). ${ }^{41}$ Membrane potentials were generated by varying the intravesicular and extravesicular $\mathrm{K}^{+}$concentrations and introducing valinomycin at the beginning of each experiment. Two solutions of vesicles were prepared in a solution of $\mathrm{KCl}(100 \mathrm{mM})$ or a $99: 1 \mathrm{NaCl} / \mathrm{KCl}$ solution $(\mathrm{NaCl}=$ $99 \mathrm{mM}, \mathrm{KCl}=1 \mathrm{mM}$ ) solution, buffered to $\mathrm{pH} 7.0$ with HEPES (10 $\mathrm{mM})$. The LUVs were then suspended in an external solution which corresponded to the generation of a neutral membrane potential, a positive membrane potential $(118 \mathrm{mV})$, or a negative potential $(-118 \mathrm{mV})$. Valinomycin in a DMSO solution ( $5 \mu \mathrm{L}, 0.1 \mathrm{~mol} \%$ ) and a $\mathrm{NaOH}$ base pulse $(5 \mathrm{mM}$ ) were added to the solutions at $t=-30 \mathrm{~s}$ before the experiment was initiated with the addition of transporter in a DMSO solution $(5 \mu \mathrm{L})$ at $t=$ 0 s. A single dose was used for each compound at a concentration that corresponded to the $\mathrm{EC}_{50}$ value determined in the NMDG-Cl HPTS assay. Full experimental methods and fluorescence plots can be viewed in the supplementary information. 
a)

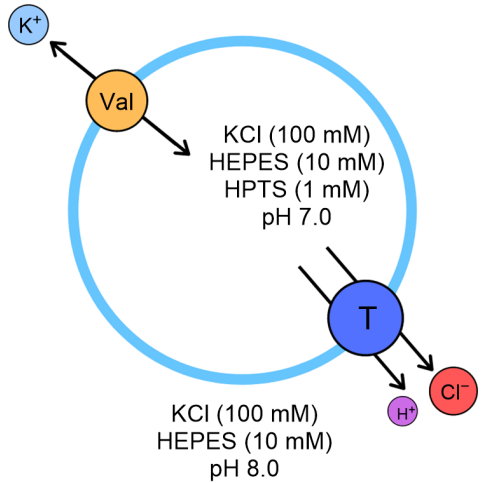

b)

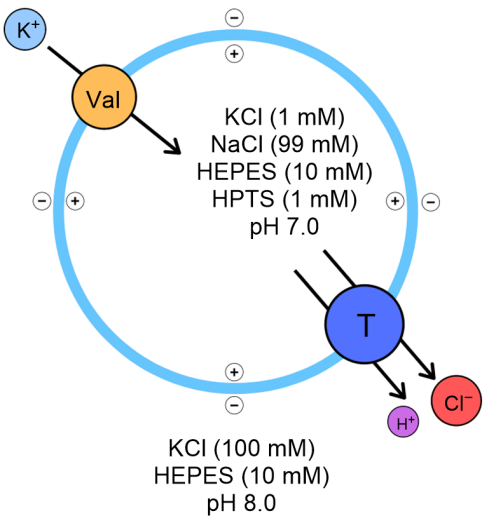

c)

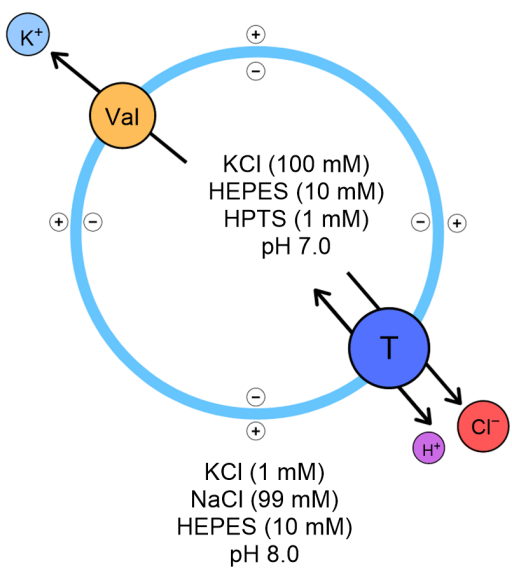

Figure 8 Schematic representation of voltage-dependent HPTS assays, showing generation of membrane potentials of 0,118 and $-118 \mathrm{mV}$ using valinomycin and a $\mathrm{K}^{+}$ gradient. All internal and external solutions are buffered by HEPES (10 mM).

There are two putative $\mathrm{H}^{+} / \mathrm{Cl}^{-}$symport mechanisms. The first involves protonation of a neutral receptor and subsequent binding of chloride as a neutral complex, followed by the diffusion of the neutral free receptors back across the membrane to complete the transport cycle. The naturally occurring anionophore prodigiosin has been shown to operate via this mechanism. ${ }^{44}$ Transport mediated by this process should be unaffected by membrane potential, as it involves the diffusion of neutral species only. A second mechanism arises when an anionophore transports chloride as a negatively charged receptor-chloride complex and diffuses back as a negatively charged deprotonated species or complex with deprotonated fatty acids. If the anionophore cannot diffuse through the membrane as a neutral anion-free receptor due to strong binding to phosphate headgroups, symport via this mechanism should be attenuated by the generation of a membrane potential because this should inhibit the diffusion of either one of the negatively charged species or complex.

The bis-urea compounds 1-5 all showed an attenuation in transport rate when either a positive or negative membrane potential was applied (Figure 9a). This provides evidence that $\mathrm{H}^{+} / \mathrm{Cl}^{-}$symport is facilitated by a non-uniport mechanism, likely due to strong interactions with the phosphate headgroups as proposed in previous voltage-dependent transport studies. ${ }^{45}$ The possibility of tautomerism of the deprotonated form of the receptor may also favour this mechanism, as this would delocalise the negative charge over a greater portion of the molecule and allow it to diffuse through the membrane more easily.

Compound $\mathbf{8}$ displayed similar voltage-dependent transport to the bis-urea compounds, however, the other thiourea compounds behaved differently under the conditions of the assays. Compounds $\mathbf{6}$ and $\mathbf{9}$ (Figure $9 \mathrm{~b}$ ) facilitated $\mathrm{pH}$ dissipation at a faster rate in the presence of a positive membrane potential, and when a negative membrane potential was applied the intravesicular solution became acidified. These findings suggest that compounds $\mathbf{6}$ and $\mathbf{9}$ can function as $\mathrm{H}^{+}$ uniporters in the presence of valinomycin, because their neutral free receptor form is able to freely diffuse across the membrane which may be a consequence of weaker interactions with the phosphate headgroups.

(a)

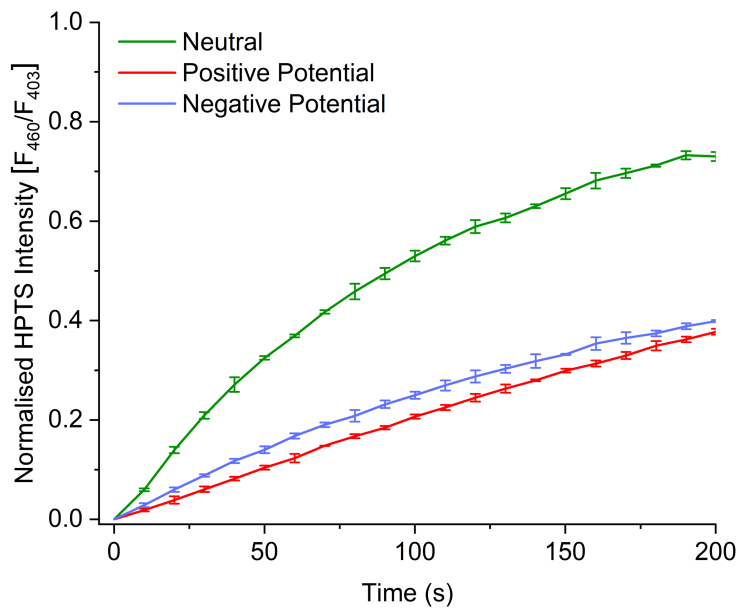


(b)

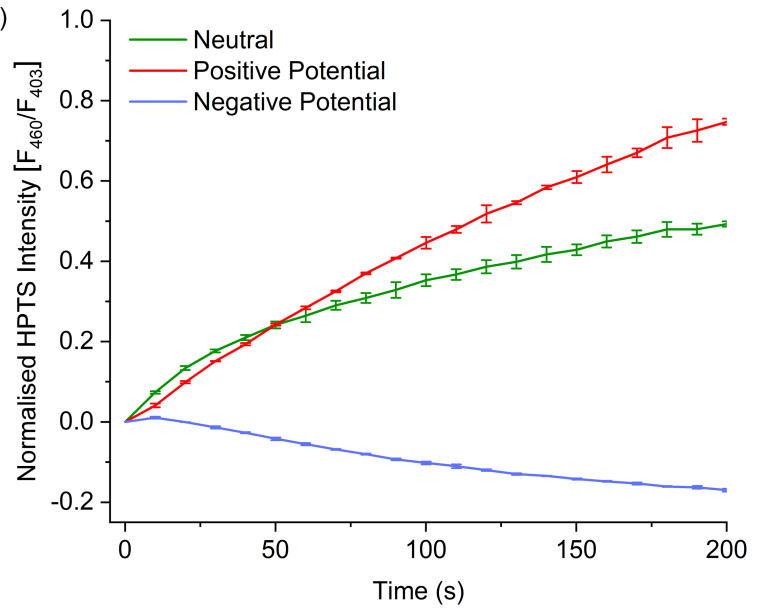

Figure 9. Voltage-dependent HPTS base pulse assay efflux plots for a) $\mathbf{3}$ (0.05 mol\%) and b) 9 ( 0.02 mol\%) at a neutral membrane potential (green), a positive membrane potential (red), and negative membrane potential (blue), generated using valinomycin based on a $\mathrm{K}^{+}$concentration gradient. Each data point is the average of two repeats with the error bars showing the standard deviation.

\section{Mechanistic studies}

Additional experiments were undertaken to identify the proton transport mechanism, and the influence of fatty acids in the lipid bilayer on the rate of transport (Figure 10). POPC vesicles were prepared with a solution of $\mathrm{NaCl}(100 \mathrm{mM})$ and HPTS $(1 \mathrm{mM})$, buffered to $\mathrm{pH} 7.0$ with HEPES $(5 \mathrm{mM})$. The vesicles were suspended in an identical external solution which was prepared without the presence of HPTS. A $\mathrm{pH}$ gradient was induced with a $\mathrm{NaOH}$ base pulse $(5 \mathrm{mM})$ and transporter was added to the experiment as a DMSO solution ( $5 \mu \mathrm{L}$ to a total volume of $2.5 \mathrm{~mL}$ ) at $\mathrm{t}=0 \mathrm{~s}$. A single dose was used for each compound corresponding to the concentration used in the voltage dependent HPTS assays. The experiments were repeated in the presence of carbonyl cyanide-mchlorophenylhydrazone (CCCP), with the protonophore being added at $t=-30 \mathrm{~s}$.

In the presence of CCCP, transport experiments can identify whether there is a $\mathrm{Cl}^{-}>\mathrm{H}^{+}$selectivity in the transport process. An increase in the rate of transport in the presence of CCCP indicates that the transport of protons is the rate-limiting step. An acceleration in $\mathrm{pH}$ dissipation was not observed for compounds 1-10 in the presence of CCCP and, in some cases, a decrease in the rate of transport was observed (Figure 11). To couple to CCCP, a transporter must be able to facilitate electrogenic chloride uniport. These results are further evidence that the acridinone-based compounds do not facilitate transport by this mechanism.

Subsequently, the vesicles were treated with bovine serum albumin (BSA) and stirred vigorously for three hours to remove trace fatty acids from the lipid bilayer. Transport experiments were repeated, and a decrease in the rate of $\mathrm{pH}$ dissipation compared to the non-treated vesicles was observed in all cases (Figure 11). The decrease in the rate of $\mathrm{pH}$ dissipation in the absence of membrane fatty acids suggest that the transporters facilitate a fatty acid-dependent $\mathrm{pH}$ dissipation pathway. Fatty acids deprotonate to release protons into the extravesicular solution and then a transporter molecule can bind to the carboxylate headgroup to mediate its transport through the bilayer to the vesicle interior. The carboxylate is then reprotonated by the intravesicular solution and can flip back to the vesicle exterior as a neutral species, thereby completing the $\mathrm{H}^{+}$transport cycle.

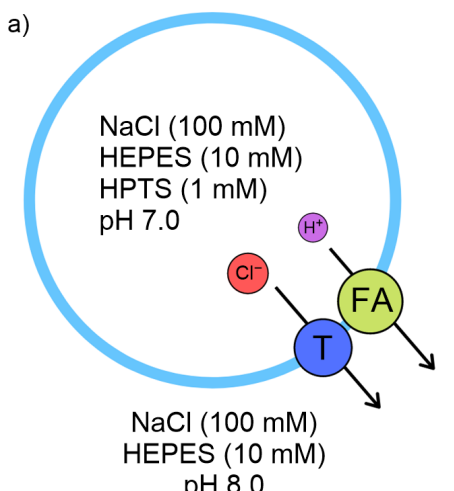

$\mathrm{pH} 8.0$

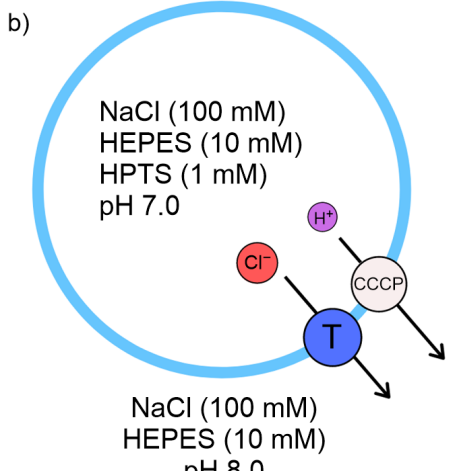
$\mathrm{pH} 8.0$

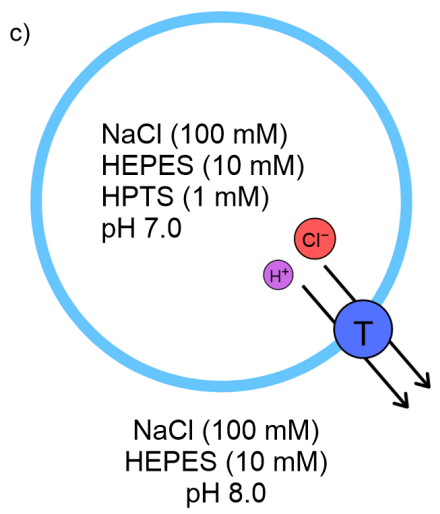

Figure 10 Schematic of the $\mathrm{KCl}$ assay, monitored by HPTS fluorescence. a) Overall pH dissipation from the transporter facilitating $\mathrm{Cl}^{-} / \mathrm{H}^{+}$cotransport via chloride transport and facilitating fatty acid flip-flop, b) overall $\mathrm{pH}$ dissipation resulting from the transporter facilitating $\mathrm{Cl}^{-}$transport coupled with the weak acid protonophore CCCP, which facilitates $\mathrm{H}^{+}$efflux, and c) overall $\mathrm{pH}$ dissipation resulting from the transporter facilitating $\mathrm{HCl}$ co-transport. 

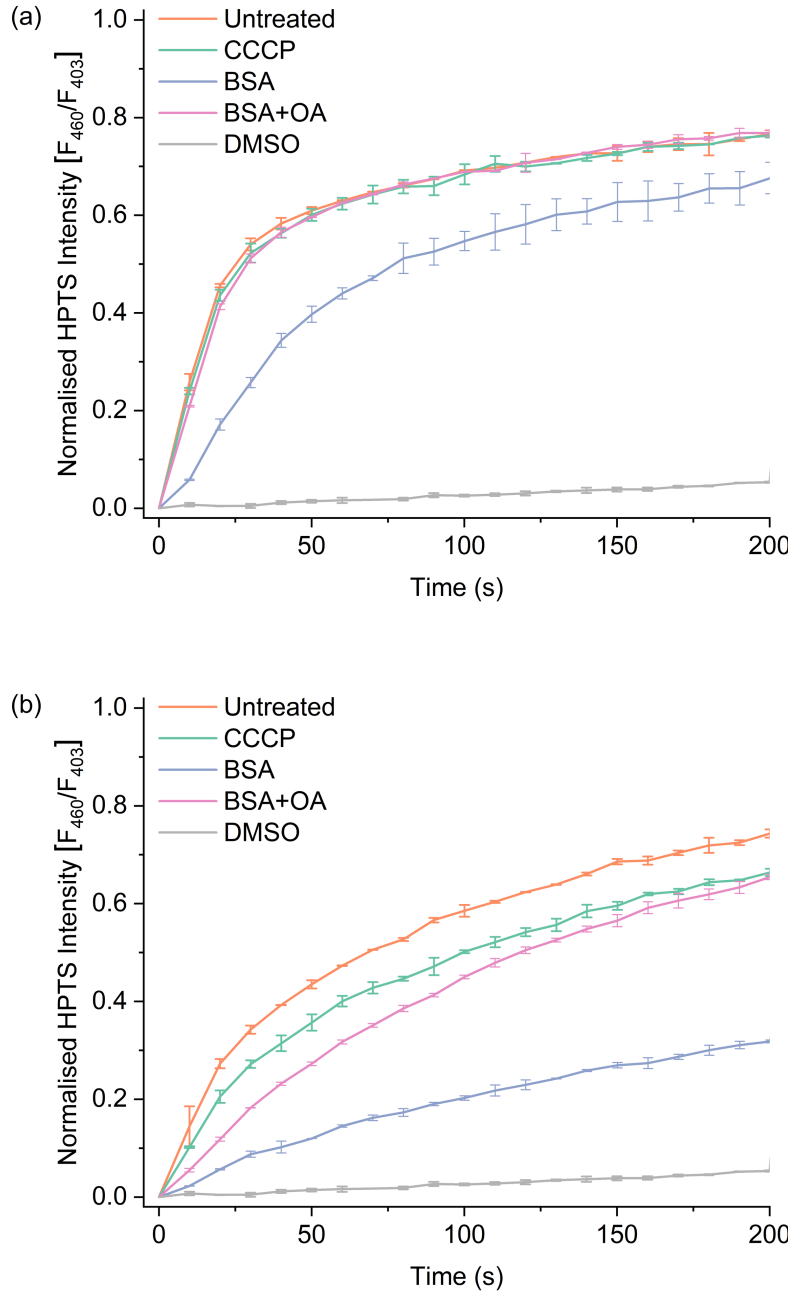

Figure 11 HPTS fluorescence for a) $\mathbf{4}(0.01 \mathrm{~mol} \%)$ and b) $\mathbf{9}(0.02 \mathrm{~mol} \%)$ as a free receptor (orange), in the presence of CCCP (green), in BSA-treated vesicles (blue used as a control.

The propensity to facilitate this process was further evidenced after the addition of oleic acid (OA) to the BSA-treated vesicles, which resulted in an increase in $\mathrm{pH}$ dissipation rate for all compounds tested (Figure 11). This means the $\mathrm{H}^{+} / \mathrm{Cl}^{-}$symport process can be at least partially ascribed to a fatty aciddependent pathway. The findings in the cationophore coupled assay indicate that the transporters, after releasing chloride, must deprotonate before moving back through the lipid bilayer due to strong interactions with the phospholipid headgroups in their charge-neutral form. However, this process can be expedited by binding a neutral transporter molecule to a deprotonated fatty acid, which then moves through the lipid bilayer as a complex. This offers an alternative $\mathrm{H}^{+} / \mathrm{Cl}^{-}$symport pathway, and accounts for the reduction in the transport rate when trace fatty acids are removed.

\section{Anion transport selectivity studies}

Recently, we have reported the suitability of 'anion gradient' assays for determining the selectivity of a transporter towards chloride over other anions (Figure 12). ${ }^{45}$ Vesicles were prepared in a solution of $\mathrm{NaCl}(100 \mathrm{mM})$ and HPTS $(1 \mathrm{mM})$, buffered to $\mathrm{pH}$ 7.0 with HEPES $(10 \mathrm{mM})$. Following this procedure, the vesicles were suspended in external solutions of $\mathrm{NaX}(100 \mathrm{mM})$, also buffered to $\mathrm{pH} 7.0$, where $\mathrm{X}^{-}=\mathrm{Cl}^{-}, \mathrm{Br}^{-}, \mathrm{NO}_{3}{ }^{-}, \mathrm{I}^{-}$, or $\mathrm{ClO}_{4}^{-}$. No base pulse was added, and the experiment was initiated by the addition of a transporter as a DMSO solution $(5 \mu \mathrm{L}$ to a total volume of $2.5 \mathrm{~mL}$ ) at $t=0 \mathrm{~s}$. Selectivity is determined by observing the maximum $\Delta \mathrm{pH}$ values reached during each experiment. If the rate of $\mathrm{HCl}$ efflux exceeds the rate of $\mathrm{HX}$ influx, then the intravesicular solution is basified, and $\Delta \mathrm{pH}$ will be a positive value. If the rate of $\mathrm{HX}$ influx is the faster process then protons will enter the vesicles at a quicker rate than protons leaving through $\mathrm{HCl}$ efflux, and therefore the $\Delta \mathrm{pH}$ value should be negative. To exhibit chloride-selective transport, a compound must return a positive $\Delta \mathrm{pH}$ value against the other anions tested.

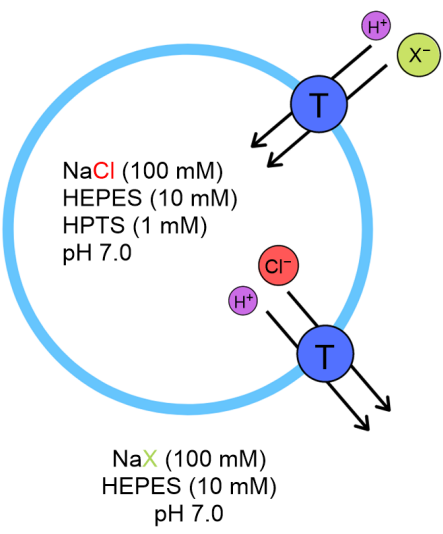

Figure 12 Schematic showing the general conditions required for the anion gradient assay. $\mathrm{X}=\mathrm{Cl}^{-}, \mathrm{Br}^{-}, \mathrm{NO}_{3}{ }^{-}, \mathrm{I}^{-}, \mathrm{ClO}_{4}^{-}$. If the transport rate of $\mathrm{HCl}>\mathrm{HX}$, then the vesicle interior is basified. If the transport rate of $\mathrm{HCl}<\mathrm{HX}$, then the vesicle interior is acidified.

The transport selectivity for compounds 1-10 generally followed the order $\mathrm{I}^{-}>\mathrm{Br}^{-}>\mathrm{Cl}^{-}>\mathrm{NO}_{3}{ }^{-}>\mathrm{ClO}_{4}{ }^{-}$. The trend for the halide anions follows the sequence predicted by the Hofmeister series, with the transport of more hydrophobic anions facilitated more efficiently. Interestingly, all compounds transported chloride at a faster rate than $\mathrm{NO}_{3}{ }^{-}$and $\mathrm{ClO}_{4}{ }^{-}$, despite the higher lipophilicity of the two anions. It is likely that the preorganised, convergent bis-(thio)urea binding site is a better geometrical match for spherical halide anions over the more complex geometries of $\mathrm{NO}_{3}{ }^{-}$and $\mathrm{ClO}_{4}{ }^{-}$. A similar $\mathrm{Cl}^{-}>\mathrm{NO}_{3}{ }^{-}$ transport selectivity was previously observed for tren-based thiourea compounds, ${ }^{45}$ and therefore the transport of $\mathrm{NO}_{3}{ }^{-}$is the rate-limiting step in the $\mathrm{Cl}^{-} / \mathrm{NO}_{3}{ }^{-}$assay for these compounds. Therefore, the true $\mathrm{Cl}^{-}$transport activity achieved by compounds 3-5 and 8-10 may have been underestimated due to poor transport of $\mathrm{NO}_{3}{ }^{-} .{ }^{46}$ Notably, compound 4 exhibited minimal transport selectivity for $\mathrm{Br}^{-}$over $\mathrm{Cl}^{-}$, and the negative $\triangle \mathrm{pH}$ value afforded by an external solution of $\mathrm{HI}$ was also small (Figure 13). By comparison, the bis-thiourea analogue 9 showed considerable $\mathrm{I}^{-}>\mathrm{Cl}^{-}$selectivity (Figure 14). The tight, planar binding site afforded by the bis-urea groups, coupled with the 
steric bulk of the 3,5-bis- $\mathrm{CF}_{3}$ substituents, creates the most $\mathrm{Cl}^{-}$ size-selective binding site of the series.

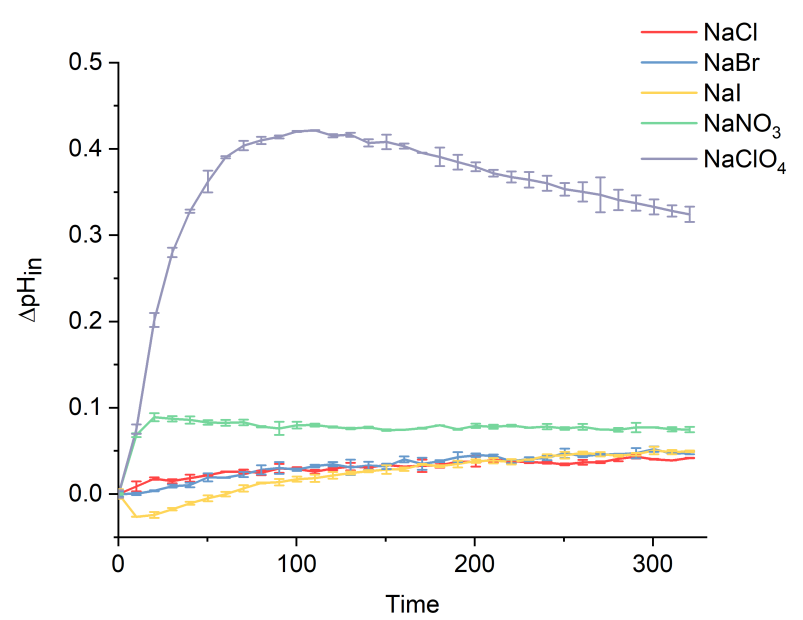

Figure 13 The anion selectivity assay for $4(0.01 \mathrm{~mol} \%$, added at time 0$)$. Initial conditions: In: NaCl (100 mM), HPTS (1 mM), HEPES (10 mM), pH 7.0; Out: NaX (100 mM), HEPES (10 $\mathrm{mM}), \mathrm{pH}$ 8.0. $[\mathrm{POPC}]=0.1 \mathrm{mM},[\mathrm{DMSO}]=5 \mu \mathrm{L}$. Error bars represent the standard deviations from two runs.

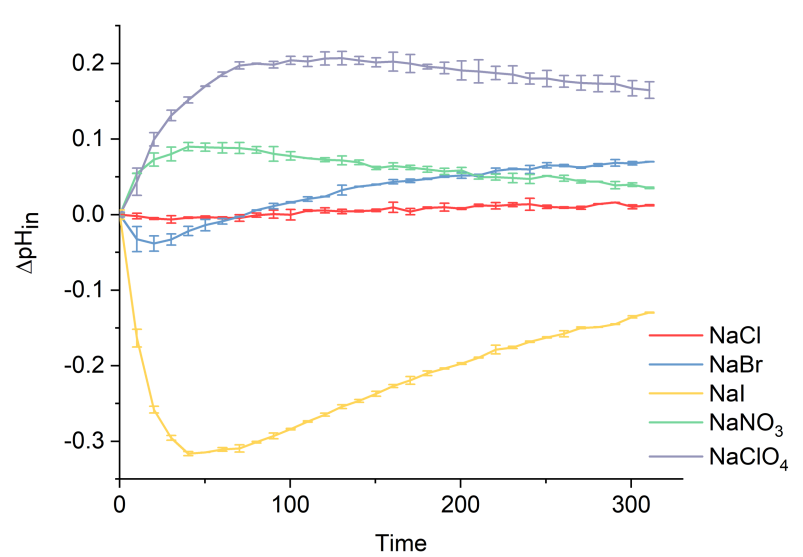

Figure 14 The anion selectivity gradient assay for $9(0.02 \mathrm{~mol} \%$, added at time 0$)$. Initial conditions: In: $\mathrm{NaCl}(100 \mathrm{mM}), \mathrm{HPTS}(1 \mathrm{mM})$, HEPES (10 mM), pH 7.0; Out: NaX (100 mM), HEPES $(10 \mathrm{mM}), \mathrm{pH} 8.0 .[\mathrm{POPC}]=0.1 \mathrm{mM},[\mathrm{DMSO}]=5 \mu \mathrm{L}$. Error bars represent the standard deviations from two runs.

\section{Experimental}

\section{General}

Experimental

Methods

Anhydrous solvents were collected from an Inert Corp PureSolv MD7 solven purification system. Deionised water was collected from a Merck Millipore Milli- $Q^{\mathrm{TM}}$ reference ultrapure water purification system.

The nuclear magnetic resonance (NMR) spectra were recorded at $300 \mathrm{~K}$ using a Bruker AVIII 500, Bruker Avance DPX 400, or a Bruker Avance 600 spectrometer. ${ }^{1} \mathrm{H}$ and ${ }^{13} \mathrm{C}$ NMR spectra were recorded at the indicated frequency, and calibrated to the residual DMSO- $d_{6}$ solvent peak ( $\delta=2.50 \mathrm{ppm}$ and $\delta=39.52 \mathrm{ppm}$, respectively). The resonances are reported as chemical shifts in ppm, multiplicity, coupling constant in $\mathrm{Hz}$, and by their relative integral. Melting points were recorded manually using a Standford Research Systems Optimelt machine, and data were reported as a range $\left({ }^{\circ} \mathrm{C}\right)$. Low resolution mass spectrometry was performed with a Bruker amaZon SL mass spectrometer using electrospray ionisation. High resolution mass spectra were recorded on a Bruker Apex II Fourier Transform Ion Cyclotron Resonance (FTICR) mass spectrometer with a $7.0 \mathrm{~T}$ magnet, fitted with an off-axis analytic electrospray source with quadrupole mass analyser, and are reported as $\mathrm{m} / \mathrm{z}$ (relative intensity).

To prepare the vesicles, a chloroform solution of POPC (37.5 mM, 4 $\mathrm{mL}$ ) was transferred to a pre-weighed round-bottom flask, and the solvent was removed using a rotary evaporator. The pressure was lowered slowly to ensure the formation of a smooth lipid film. Subsequently, the film was dried in vacuo for 4-24 h, and the mass of lipid was recorded. The lipids were rehydrated with $4 \mathrm{~mL}$ of the respective internal solution (this number should correspond to the volume of POPC solution used initially) and vortexed until all lipids were removed from the sides of the flask and were suspended in solution. The lipids were subjected to 9 cycles of freeze-thaw by freezing using a dry ice/acetone bath and thawing in lukewarm water. Following this, the vesicles were left to rest at room temperature for $30 \mathrm{~min}$. The lipids were extruded through a $200 \mathrm{~nm}$ polycarbonate membrane 25 times to form monodisperse vesicles. Only $1 \mathrm{~mL}$ of solution was extruded at a time before being collected. Finally, any residual unencapsulated salt from the internal solution was either removed via dialysis for $12 \mathrm{~h}$ in the desired external solution or through size-exclusion using a B19 column packed with hydrated G-25 Sephadex ${ }^{\circledR}$, which had been pre-saturated with the respective external solution. The lipid suspensions were diluted with the external solution to afford a stock solution $(10 \mathrm{~mL})$ of a known concentration. The ISE assayd were conducted on the Fisherbrand ${ }^{\mathrm{TM}}$ Accumet $^{\mathrm{TM}}$ Chloride Combination Electrode, and the HPTS transport fluorescence data was recorded on an Agilent Cary Eclipse Fluorescence Spectrophotometer.

\section{1,9-Bisphenylurea-9(10H)-acridinone (1)}

Compound $\mathbf{1}$ was synthesised using a literature procedure. ${ }^{11}$ 1,9-Diaminoacridinone (100 $\mathrm{mg}, 0.44 \mathrm{mmol}$ ) was dissolved in dry DMF ( $5 \mathrm{~mL})$ and stirred under nitrogen. Separately, phenyl isocyanate $(0.15 \mathrm{~mL}, 1.33 \mathrm{mmoL})$ was dissolved in DMF $(1 \mathrm{~mL})$ and added dropwise to the first solution. This reaction was left for $3 \mathrm{~h}$, by which time a light brown precipitate had formed. This precipitate was filtered, suspended, and sonicated in 1:1 v/v diethyl ether/hexane $(100 \mathrm{~mL})$ for $30 \mathrm{~min}$ and then filtered again. This was washed with further portions of diethyl ether ( 3 x $30 \mathrm{~mL}$ ) before being dried in vacuo to yield a brown solid (127.5 mg, $0.27 \mathrm{mmol}, 62 \%$ ). Analytical data matched that of this compound in the literature.

Mp $=361-364^{\circ} \mathrm{C}$ (decomposition)

${ }^{1}$ H NMR (500 MHz, DMSO-d 6 ) $\delta$ ppm $10.65(1 \mathrm{H}, \mathrm{s}), 8.9(2 \mathrm{H}, \mathrm{s})$, $8.74(2 \mathrm{H}, \mathrm{s}), 8.13$ (2 H, d, J 7.6), 7.69 (2 H, d, J 6.7), 7.42 (4 H, d, J 7.2), 7.3 (2 H, d, J 7.5), 7.14 (4 H, t, J 7.8), $6.94(2 \mathrm{H}, \mathrm{t}, \mathrm{J} 7.1)$; ${ }^{13} \mathrm{C}\left\{{ }^{1} \mathrm{H}\right\}$ NMR $\left(101 \mathrm{MHz}, \mathrm{DMSO}-\mathrm{d}_{6}\right) \delta \mathrm{ppm} 177.4,154.4,139.8$, 136.1, 129.7, 129.1, 127.6, 123.5, 122.0, 121.6, 119.1

LR-MS (ESI $\left.{ }^{-}\right) \quad m / z \quad 498.22 \quad\left[\mathrm{M}-\mathrm{H}^{-}\right.$; HR-MS $\left(\mathrm{ESI}^{+}\right)$calcd for $\mathrm{C}_{27} \mathrm{H}_{21} \mathrm{~N}_{5} \mathrm{O}_{3}[\mathrm{M}+\mathrm{H}]^{+}:$464.17172, found $\mathrm{m} / \mathrm{z} 464.17164$.

\section{1,9-Bis(4-(trifluoromethyl)phenyl)urea-9(10H)-acridinone (2)}

1,9-Diaminoacridinone (50 $\mathrm{mg}, 0.22 \mathrm{mmol}$ ) was dissolved in DMSO (3 mL). 4-(Trifluoromethyl)phenyl isocyanate $(0.11 \mathrm{~mL}$, $0.78 \mathrm{mmol}$ ) was added dropwise, and the reaction left to stir for $15 \mathrm{~min}$. Next, the solution was poured onto ice-cold deionised 
water $(25 \mathrm{~mL})$ and a precipitate formed, which was filtered. This precipitate was then washed with water $(3 \times 30 \mathrm{~mL})$, hexane $(3$ $x 15 \mathrm{~mL})$, and suspended in $1: 1 \mathrm{v} / \mathrm{v}$ ethyl acetate/hexane $(50 \mathrm{~mL})$ before being sonicated for $30 \mathrm{~min}$. The solid was again filtered, washed with a further portion of 1:1 50\% ethyl acetate/hexane, then dried in vacuo $(83 \mathrm{mg}, 0.14 \mathrm{mmol}, 63 \%)$.

$\mathbf{M p}=333-336^{\circ} \mathrm{C}$ (decomposition)

${ }^{1} \mathrm{H}$ NMR $\left(600 \mathrm{MHz}\right.$, DMSO-d $\left.d_{6}\right) \delta$ ppm $10.50(1 \mathrm{H}, \mathrm{s}), 9.4(2 \mathrm{H}, \mathrm{s})$, $8.91(2 \mathrm{H}, \mathrm{s}), 8.15(2 \mathrm{H}, \mathrm{dd}, \mathrm{J} 8.1,1.5), 7.68(2 \mathrm{H}, \mathrm{dd}, \mathrm{J}$ 7.6, 1.5), $7.56(4 \mathrm{H}, \mathrm{d}, \mathrm{J} 8.5), 7.35\left(4 \mathrm{H}, \mathrm{d}, \mathrm{J}\right.$ 8.7), $7.31\left(2 \mathrm{H}, \mathrm{t}, \mathrm{J}\right.$ 7.8); ${ }^{13} \mathrm{C}\left\{{ }^{1} \mathrm{H}\right\}$ NMR (101 MHz, DMSO-d 6 ) $\delta$ ppm 176.9 (s), 153.6 (s), 143.1 (s), 135.7 (s), 129.6 (s), 126.7 (s), 125.8 (s), 124.4 (d), 123.2 (s), 121.9 (d), 121.5 (s), 121.2 (s), 117.9 (s). note Lack of definition and peak overlap restricted process of quarter splitting. LR-MS (ESI-) $\mathrm{m} / z$ 598.19 [M-H] $]^{-}$; HR-MS $\left(\mathrm{ESI}^{+}\right)$calcd for $\mathrm{C}_{29} \mathrm{H}_{19} \mathrm{~F}_{6} \mathrm{~N}_{5} \mathrm{O}_{3}[\mathrm{M}+\mathrm{H}]^{+}$: 600.14649 , found $m / z$ 600.14625.

\section{1,9-Bis(4-nitrophenyl)urea-9(10H)-acridinone (3)}

1,9-Diaminoacridinone (50 $\mathrm{mg}, 0.22 \mathrm{mmol}$ ) and 4-nitrophenyl isocyanate $(80 \mathrm{mg}, 0.49 \mathrm{mmol}$ ) were dissolved in DMSO $(3 \mathrm{~mL})$. The reaction was left to stir for $15 \mathrm{~min}$. Next, the solution was poured onto ice-cold deionised water $(25 \mathrm{~mL})$ and a precipitate formed, which was filtered. This precipitate was then washed with water $(3 \times 30 \mathrm{~mL})$, hexane $(3 \times 15 \mathrm{~mL})$, and suspended in hot methanol $(200 \mathrm{~mL}$ ) before being sonicated for $30 \mathrm{~min}$. The solid was again filtered, washed with copious amounts of boiling methanol then dried in vacuo. (35 mg, $0.063 \mathrm{mmol}, 29 \%$ ).

$\mathbf{M p}=328-331{ }^{\circ} \mathrm{C}$ (decomposition)

${ }^{1} \mathrm{H}$ NMR $\left(600 \mathrm{MHz}\right.$, DMSO- $\left.d_{6}\right) \delta \mathrm{ppm} 10.18(1 \mathrm{H}, \mathrm{s}), 9.66(1 \mathrm{H}, \mathrm{s})$ $8.97(1 \mathrm{H}, \mathrm{s}), 8.17(2 \mathrm{H}, \mathrm{d}, 8.2), 7.90(4 \mathrm{H}, \mathrm{d}, 8.6), 7.68(2 \mathrm{H}, 2,7.6)$, $7.55(4 \mathrm{H}, \mathrm{d}, 8.8), 7.32(2 \mathrm{H}, \mathrm{m}) ;{ }^{13} \mathrm{C}\left\{{ }^{1} \mathrm{H}\right\}$ NMR $(101 \mathrm{MHz}$, DMSO-

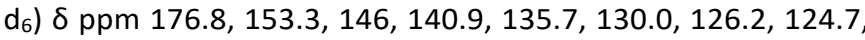
123.6, 121.5, 121.2, 117.4

LR-MS (ESI $\left.{ }^{-}\right) \mathrm{m} / z$ 588.21 [M+Cl] ${ }^{-}$; HR-MS (ESI ${ }^{+}$) calcd for $\mathrm{C}_{27} \mathrm{H}_{21} \mathrm{~N}_{7} \mathrm{O}_{7}[\mathrm{M}+\mathrm{H}]^{+}:$554.14187, found $m / z$ 554.14146.

\section{1,9-Bis(3,5-bis-(trifluoromethyl)phenyl)urea-9(10H)-acridinone (4)}

1,9-Diaminoacridinone $(50 \mathrm{mg}, 0.22 \mathrm{mmol}$ ) was dissolved in DMSO (3 mL). Separately, 3,5-bis(trifluoromethyl)phenyl isocyanate $(0.15 \mathrm{~mL}, 0.889 \mathrm{mmol})$ was dissolved in DMSO (2 $\mathrm{mL}$ ), and this was added dropwise to the reaction mixture. The reaction was left to stir for $15 \mathrm{~min}$. Next, the solution was poured onto ice-cold deionised water $(25 \mathrm{~mL})$, and a green precipitate formed, which was filtered. This precipitate was then washed with water $(3 \times 30 \mathrm{~mL})$ and hexane $(3 \times 15 \mathrm{~mL})$. The solid was washed with a further portion of $1: 1 \mathrm{v} / \mathrm{v}$ diethyl ether/hexane solution and dried in vacuo to give a light green powder (90 mg, $0.12 \mathrm{mmol}, 55 \%$ ).

$\mathrm{Mp}=189-192^{\circ} \mathrm{C}$

${ }^{1} \mathrm{H}$ NMR $\left(600 \mathrm{MHz}, \mathrm{DMSO}-d_{6}\right) \delta \mathrm{ppm} 10.04(1 \mathrm{H}, \mathrm{s}), 9.67(2 \mathrm{H}, \mathrm{s})$ $9.05(2 \mathrm{H}, \mathrm{s}), 8.17(2 \mathrm{H}, \mathrm{dd}, \mathrm{J}$ 8.3, 1.5), $7.95(4 \mathrm{H}, \mathrm{d}, \mathrm{J} 1.7), 7.67$ (2 $\mathrm{H}$, dd, J 7.6, 1.4), $7.38(2 \mathrm{H}, \mathrm{t}, \mathrm{J} 1.7), 7.32(2 \mathrm{H}, \mathrm{t}, \mathrm{J} 7.8) ;{ }^{13} \mathrm{C}\left\{{ }^{1} \mathrm{H}\right\}$ NMR $\left(101 \mathrm{MHz}, \mathrm{DMSO}-\mathrm{d}_{6}\right) \delta \mathrm{ppm} 176.8,153.4,141.5,135.6$, 130.2 (dd, J 65.8, 33.1), 130.0, 126.1, 123.8, 123.1 (q, J 272.5), $121.5,121.2,117.3,114.1$

LR-MS (ESI $\left.{ }^{+}\right) \mathrm{m} / z$ 758.19 [M+Na] ${ }^{+}$; HR-MS (ESI+) calcd for $\mathrm{C}_{31} \mathrm{H}_{17} \mathrm{~F}_{12} \mathrm{~N}_{5} \mathrm{O}_{3}[\mathrm{M}+\mathrm{Na}]^{+}:$758.10320, found $\mathrm{m} / z$ 758.10303.

\section{1,9-Bis(4-(pentafluorosulfanyl)phenyl)urea-9(10H)-acridinone (5)}

This synthesis was adapted from a literature procedure. ${ }^{47} \mathrm{~A}$ solution of 4- pentafluorosulfanylaniline $(150 \mathrm{mg}, 0.67 \mathrm{mmol})$ in toluene $(15 \mathrm{~mL})$ was treated with triphosgene $(135 \mathrm{mg}, 0.44$ $\mathrm{mmol})$. Immediately, triethylamine $(0.16 \mathrm{~mL}, 1.18 \mathrm{mmol})$ was added, and the reaction mixture stirred at $70^{\circ} \mathrm{C}$ for $2 \mathrm{~h}$. After this, pentane $(1 \mathrm{~mL})$ was added to elicit the formation of a white precipitate. This was filtered off and the pentane removed in vacuo to give 4-(pentafluorosulfanyl)phenyl isocyanate dissolved in toluene, which was used immediately in the next reaction. 1,9-Diaminoacridinone $(50 \mathrm{mg}, 0.22 \mathrm{mmol})$ was dissolved in DMSO $(5 \mathrm{~mL})$ and added to the reaction mixture. This was stirred for $3 \mathrm{~h}$ and, following this, the toluene was removed in vacuo. Next, the DMSO solution was poured into ice water $(30 \mathrm{~mL})$ to yield a light brown precipitate. This was washed with a small amount of $1: 1 \mathrm{v} / \mathrm{v}$ ethyl acetate:hexane solution $(5 \mathrm{~mL})$ followed by copious amounts of $1: 1 \mathrm{v} / \mathrm{v}$ diethyl ether:hexane solution to leave a dark brown solid, which was dried in vacuo (99 $\mathrm{mg}, 0.14 \mathrm{mmol}, 63 \%$ ).

$\mathbf{M p}=259-262{ }^{\circ} \mathrm{C}$ (decomposition)

${ }^{1} \mathrm{H}$ NMR $\left(500 \mathrm{MHz}\right.$, DMSO-d $\left.d_{6}\right) \delta \mathrm{ppm} 10.52(1 \mathrm{H}, \mathrm{s}), 9.48(2 \mathrm{H}, \mathrm{s})$, $8.90(2 \mathrm{H}, \mathrm{s}), 8.16(2 \mathrm{H}, \mathrm{d}, \mathrm{J}$ 8.1), $7.66(2 \mathrm{H}, \mathrm{d}, \mathrm{J} 7.4), 7.54(8 \mathrm{H}, \mathrm{m})$, $7.31(2 \mathrm{H}, \mathrm{t}, \mathrm{J} 7.8) ;{ }^{13} \mathrm{C}\left\{{ }^{1} \mathrm{H}\right\}$ NMR (101 MHz, DMSO-d 6 ) $\delta \mathrm{ppm}$ $177.3,154.0,143.3,136.2,130.2,127.0,126.9,123.9,122.0$, $121.7,118.1$. ( $\mathrm{SF}_{5} \alpha$-carbon is not visible due to quintet splitting) LR-MS (ESI+) $\mathrm{m} / \mathrm{z} 738.20 \quad[\mathrm{M}+\mathrm{Na}]^{+}$; HR-MS (ESI+) calcd for $\mathrm{C}_{27} \mathrm{H}_{16} \mathrm{~F}_{10} \mathrm{~N}_{5} \mathrm{O}_{3} \mathrm{~S}_{2}[\mathrm{M}+\mathrm{Na}]^{+}:$738.06618, found $\mathrm{m} / z$ 738.06477.

\section{1,9-Bisphenylthiourea-9(10H)-acridinone (6)}

This compound was synthesised from a literature procedure. ${ }^{11}$ 1,9-Diaminoacridinone (100 $\mathrm{mg}, 0.44 \mathrm{mmol}$ ) was dissolved in dry DMF (14 $\mathrm{mL}$ ) and stirred under nitrogen. Separately, phenyl isothiocyanate $(1.05 \mathrm{~mL}, 8.8 \mathrm{mmol})$ was dissolved in dry DMF, and this was added dropwise to the first solution. This reaction was stirred for $3 \mathrm{~h}$ before the solvent was removed. The resultant solid was treated with $1: 1 \mathrm{v} / \mathrm{v}$ diethyl ether/hexane (100 mL), sonicated for $20 \mathrm{~min}$ and filtered. The resultant solid was washed with portions of diethyl ether $(3 \times 20 \mathrm{~mL})$ and methanol $(3 \times 20 \mathrm{~mL})$ to leave a yellow solid. This was then dried in vacuo to yield the final compound (117 $\mathrm{mg}, 0.24 \mathrm{mmol}, 54 \%$ ). Analytical data matched that of this compound in the literature. $\mathrm{Mp}=297-300^{\circ} \mathrm{C}$ (decomposition)

${ }^{1} \mathrm{H}$ NMR $\left(500 \mathrm{MHz}, \mathrm{DMSO}-d_{6}\right) \delta \mathrm{ppm} 10.11(2 \mathrm{H}, \mathrm{s}), 9.79(2 \mathrm{H}, \mathrm{s})$, $9.19(1 \mathrm{H}, \mathrm{s}), 8.19(2 \mathrm{H}, \mathrm{d}, \mathrm{J}$ 7.9), $7.67(2 \mathrm{H}, \mathrm{d}, \mathrm{J} 7.2), 7.51(4 \mathrm{H}, \mathrm{d}$, J 7.6), 7.31 (2 H, d, J 7.7), 7.27 (4 H, t, J 7.5), $7.13(2 \mathrm{H}, \mathrm{t}, \mathrm{J}$ 7.1); ${ }^{13} \mathrm{C}\left\{{ }^{1} \mathrm{H}\right\}$ NMR (101 MHz, DMSO-d 6 ) $\delta \mathrm{ppm} 181.9,177.4,139.5$, $137.2,133.5,128.9,128.1,125.4,125.1,125.0,121.8,121.6$. LR-MS (ESI+) $\mathrm{m} / z$ 518.13 [M+Na] ; HR-MS (ESI+) calcd for $\mathrm{C}_{27} \mathrm{H}_{21} \mathrm{~N}_{5} \mathrm{OS}_{2}[\mathrm{M}+\mathrm{Na}]^{+}:$518.10797, found $\mathrm{m} / \mathrm{z} 518.10826$.

\section{1,9-Bis(4-(trifluoromethyl)phenyl)thiourea-9(10H)-acridinone (7)}

1,9-Diaminoacridinone (65 $\mathrm{mg}, 0.29 \mathrm{mmol}$ ) and 4(trifluoromethyl)phenyl isothiocyanate $(196 \mathrm{mg}, 0.64 \mathrm{mmol})$ were dissolved in DMSO $(3 \mathrm{~mL})$. The reaction was left to stir for $15 \mathrm{~min}$. Next, the solution was poured onto ice-cold deionised water $(25 \mathrm{~mL})$ and a precipitate formed, which was filtered. This 
precipitate was then washed with water $(3 \times 30 \mathrm{~mL})$ and dried in vacuo. Next, the compound was washed with hexane $(3 \times 15$ $\mathrm{mL})$, and 1:1 $\mathrm{v} / \mathrm{v}$ diethyl ether/hexane mixture $(3 \times 15 \mathrm{~mL})$ and then dried in vacuo (103 $\mathrm{mg}, 0.16 \mathrm{mmol}, 56 \%$ ).

$\mathrm{Mp}=218-221^{\circ} \mathrm{C}$

${ }^{1} \mathrm{H}$ NMR $\left(500 \mathrm{MHz}, \mathrm{DMSO}-d_{6}\right) \delta \mathrm{ppm} 10.43(2 \mathrm{H}, \mathrm{s}), 10.03(2 \mathrm{H}$, s), $9.14(1 \mathrm{H}, \mathrm{s}), 8.22(2 \mathrm{H}, \mathrm{dd}, \mathrm{J} 8.2,1.5), 7.72(4 \mathrm{H}, \mathrm{d}, \mathrm{J}$ 8.3), 7.68 (2 H, dd, J 7.5, 1.2), $7.49\left(4 \mathrm{H}, \mathrm{d}, \mathrm{J}\right.$ 8.4), $7.33\left(2 \mathrm{H}, \mathrm{t}, \mathrm{J}\right.$ 7.8); ${ }^{13} \mathrm{C}\left\{{ }^{1} \mathrm{H}\right\}$ NMR $\left(101 \mathrm{MHz}, \mathrm{DMSO}-\mathrm{d}_{6}\right) \delta \mathrm{ppm} 181.2,176.9,142.8,136.6$, 133.0, 127.3, 125.4, 125.0, 124. 4 (q, J 32.1), 124.2 (q, J 271.5), $123.5,121.4,121.3$.

LR-MS (ESI $\left.{ }^{-}\right) \quad m / z \quad 630.29$ [M-H] $^{-}$; HR-MS (ESI ${ }^{+}$) calcd for $\mathrm{C}_{29} \mathrm{H}_{19} \mathrm{~F}_{6} \mathrm{~N}_{5} \mathrm{OS}_{2}[\mathrm{M}+\mathrm{H}]^{+}:$: 632.10080, found $\mathrm{m} / \mathrm{z}$ 632.10069.

\section{1,9-Bis(4-nitrophenyl)thiourea-9(10H)-acridinone (8)}

1,9-Diaminoacridinone (50 $\mathrm{mg}, 0.22 \mathrm{mmol}$ ) and 4-nitrophenyl isothiocyanate (200 mg, $1.11 \mathrm{mmol}$ ) were dissolved in DMSO (3 $\mathrm{mL}$ ). The reaction was left to stir for $15 \mathrm{~min}$. Next, the solution was poured onto ice-cold deionised water $(25 \mathrm{~mL})$ and a precipitate formed, which was filtered. This precipitate was then washed with water $(3 \times 30 \mathrm{~mL})$, hexane $(3 \times 15 \mathrm{~mL})$, and suspended in diethyl ether $(100 \mathrm{~mL})$ before being sonicated for $30 \mathrm{~min}$. The solid was again filtered, washed with another portion of diethyl ether then dried in vacuo $(55 \mathrm{mg}, 0.094 \mathrm{mmol}$, 42\%).

$\mathrm{Mp}=137-140^{\circ} \mathrm{C}$

${ }^{1} \mathrm{H}$ NMR $\left(500 \mathrm{MHz}\right.$, DMSO- $\left.d_{6}\right) \delta \mathrm{ppm} 10.63(2 \mathrm{H}, \mathrm{s}), 10.17(2 \mathrm{H}$, s), $9.07(1 \mathrm{H}, \mathrm{s}), 8.23(2 \mathrm{H}, \mathrm{d}, \mathrm{J}$ 8.9), $7.98(4 \mathrm{H}, \mathrm{d}, \mathrm{J}$ 9.0), $7.77(4 \mathrm{H}$, d, J 9.0), $7.68\left(2 \mathrm{H}, \mathrm{d}, \mathrm{J}\right.$ 7.3), $7.34(2 \mathrm{H}, \mathrm{t}, \mathrm{J} 7.9) ;{ }^{13} \mathrm{C}\left\{{ }^{1} \mathrm{H}\right\}$ NMR (101 $\mathrm{MHz}$, DMSO-d $\left.\mathrm{d}_{6}\right) \delta \mathrm{ppm} 180.9,176.8,145.6,142.4,136.4,132.8$, 127.1, 125.1, 124.0, 122.0, 121.4.

LR-MS $\left(\mathrm{ESI}^{+}\right) \mathrm{m} / \mathrm{z}$ 586.14 [M+H]+; HR-MS (ESI+) calcd for $\mathrm{C}_{27} \mathrm{H}_{19} \mathrm{~N}_{7} \mathrm{O}_{5} \mathrm{~S}_{2}[\mathrm{M}+\mathrm{H}]^{+}:$586.09618, found $\mathrm{m} / \mathrm{z}$ 586.09567.

\section{1,9-Bis(3,5-bis-(trifluoromethyl)phenyl)thiourea-9(10H)-acridinone} (9)

1,9-Diaminoacridinone (50 $\mathrm{mg}, 0.22 \mathrm{mmol}$ ) was dissolved in DMSO (3 mL). Separately, 3,5-bis(trifluoromethyl)phenyl isothiocyanate (144.52 $\mathrm{mg}, 0.533 \mathrm{mmol}$ ) was dissolved in DMSO $(2.5 \mathrm{~mL})$, and this was added dropwise to the reaction mixture. The reaction was left to stir for $15 \mathrm{~min}$. Next, the solution was poured onto ice-cold deionised water $(25 \mathrm{~mL})$, and a yellow/green precipitate formed, which was filtered. This precipitate was then washed with water $(3 \times 30 \mathrm{~mL})$ and hexane $(3 \times 15 \mathrm{~mL})$. Next, the solid suspended in a 1:9 v/v diethyl ether/hexane mixture and sonicated for 30 mins. This was filtered, washed with further portions of $10 \%$ diethyl:ether:hexane solution, and dried in vacuo to give the final light yellow solid (75 mg, $0.098 \mathrm{mmol}, 44 \%$ ).

$\mathrm{Mp}=153-156^{\circ} \mathrm{C}$

${ }^{1} \mathbf{H}$ NMR $\left(600 \mathrm{MHz}\right.$, DMSO- $\left.d_{6}\right) \delta$ ppm $10.23(2 \mathrm{H}, \mathrm{s}), 10.15(2 \mathrm{H}$, s), $9.00(1 \mathrm{H}, \mathrm{s}), 8.08(2 \mathrm{H}, \mathrm{d}, \mathrm{J} 8.2), 8.00(4 \mathrm{H}, \mathrm{s}), 7.58(2 \mathrm{H}, \mathrm{d}, \mathrm{J}$ 7.5), $7.53(2 \mathrm{H}, \mathrm{s}), 7.19(2 \mathrm{H}, \mathrm{t}, \mathrm{J} 7.8) ;{ }^{13} \mathrm{C}\left\{{ }^{1} \mathrm{H}\right\}$ NMR $(101 \mathrm{MHz}$,

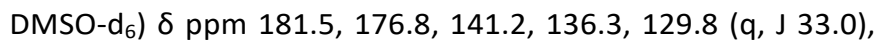
126.6, 125.2, 124.0, 123.1 (q, J 272.8), 121.6, 117.3.

LR-MS $\left(\mathrm{ESI}^{+}\right) \mathrm{m} / \mathrm{z} 790.07 \quad[\mathrm{M}+\mathrm{Na}]^{+}$; HR-MS $\left(\mathrm{ESI}^{+}\right)$calcd for $\mathrm{C}_{31} \mathrm{H}_{17} \mathrm{~F}_{12} \mathrm{~N}_{5} \mathrm{OS}_{2}[\mathrm{M}+\mathrm{H}]^{+}:$768.07555, found $\mathrm{m} / \mathrm{z} 768.07574$.

\section{1,9-Bis(4-(pentafluorosulfanyl)phenyl)thiourea-9(10H)-acridinone} (10)

4-pentafluorosulfanylaniline (410 $\mathrm{mg}, 1.86 \mathrm{mmol}$ ) was dissolved in dichloromethane $(15 \mathrm{~mL})$. Thiophosgene $(0.16 \mathrm{~mL}, 2.05$ $\mathrm{mmol}$ ) was added, followed by a layer of saturated aqueous $\mathrm{NaHCO}_{3}$ solution $(20 \mathrm{~mL})$ to trap any volatile thiophosgene. The mixture was stirred gently at room temperature for $12 \mathrm{~h}$. Next, the aqueous layer was removed, and the organic layer dried with magnesium sulfate for $1 \mathrm{~h}$. The solvent was removed in vacuo, and the resultant solid used immediately in the subsequent reaction. 1,9-Diaminoacridinone $(50 \mathrm{mg}, 0.25$ $\mathrm{mmol}$ ) and 4-(pentafluorosulfanyl)phenyl isothiocyanate (140 $\mathrm{mg}, 0.54 \mathrm{mmol}$ ) were dissolved in dry DMSO $(2.5 \mathrm{~mL})$ and stirred under $\mathrm{N}_{2}$. This reaction was stirred for $3 \mathrm{~h}$ before the solvent was poured into ice water. The resultant precipitate was filtered, then treated with 1:1 v/v diethyl ether/hexane (100 $\mathrm{mL}$ ), sonicated for $20 \mathrm{~min}$ and filtered. The resultant solid was washed with portions of a 1:1 v/v diethyl ether/hexane mixture $(3 \times 20 \mathrm{~mL}$ ) to leave a green/brown solid. The solid was then dried in vacuo to yield the final compound $(61 \mathrm{mg}, 0.08 \mathrm{mmol}$, $33 \%$ yield).

\section{$M p=245-248^{\circ} \mathrm{C}$}

${ }^{1} \mathrm{H}$ NMR $\left(400 \mathrm{MHz}\right.$, DMSO- $\left.d_{6}\right) \delta$ ppm $10.48(2 \mathrm{H}, \mathrm{s}), 10.08(2 \mathrm{H}$, s), $9.14(1 \mathrm{H}, \mathrm{s}), 8.22(2 \mathrm{H}, \mathrm{d}, \mathrm{J}$ 8.1), $7.7(10 \mathrm{H}, \mathrm{m}), 7.33(2 \mathrm{H}, \mathrm{t}, \mathrm{J}$ 7.9); ${ }^{13} \mathrm{C}\left\{{ }^{1} \mathrm{H}\right\}$ NMR (101 MHz, DMSO-d $\mathrm{d}_{6} \delta \mathrm{ppm} 181.7,177.3$, $148.5(\mathrm{~m}), 143.0,137.0,133.5,127.6,126.5,125.5,123.5$, 121.9, 121.8

LR-MS (ESI $\left.{ }^{-}\right) \mathrm{m} / \mathrm{z} 783.66[\mathrm{M}+\mathrm{Cl}]^{-}$; HR-MS $\left(\mathrm{ESI}^{+}\right)$calcd for $\mathrm{C}_{27} \mathrm{H}_{19} \mathrm{~F}_{10} \mathrm{~N}_{5} \mathrm{OS}_{4}[\mathrm{M}+\mathrm{H}]^{+}:$748.03855, found $\mathrm{m} / z$ 748.03801.

\section{Conclusions}

A series bis-ureas and bis-thioureas appended to a central acridinone scaffold were synthesised, and their chloride binding and transport properties investigated. Compounds $\mathbf{3}$ and $\mathbf{4}$ are among the most potent transporters reported by our group to date. Extensive mechanistic studies revealed the transporters function predominantly as $\mathrm{HCl}$ cotransporters and diffuse back as deprotonated species or complexes with deprotonated fatty acids due to strong interactions between the phospholipid headgroups and the neutral receptors. The electroneutral $\mathrm{HCl}$ transport facilitated by these compounds at low-dose concentrations highlights their potential to disrupt cellular $\mathrm{pH}$ gradients and find application as powerful anti-cancer agents.

\section{Author Contributions}

DAM conducted the synthesis, binding, and anion transport studies. LKM conducted the crystallography and wrote the crystallography section of the paper. DAM and PAG wrote the remainder of the manuscript. PAG directed the research.

\section{Conflicts of interest}


There are no conflicts to declare.

\section{Acknowledgements}

DAM, LKM and PAG acknowledge and pay respect to the Gadigal people of the Eora Nation, the traditional owners of the land on which we research, teach and collaborate at the University of Sydney. PAG thanks the Australian Research Council (DP200100453) and the University of Sydney for funding.

\section{Notes and references}

1 J.T. Davis, P.A. Gale and R. Quesada, Chem. Soc. Rev., 2020, 49, 6056-6086; X. Wu, A.M. Gilchrist and P.A. Gale, Chem, 2020, 6, 1296-1309.

2 S.-H. Park, S.-H. Park, E.N.W. Howe, J.Y. Hyun, L.-J. Chen, I. Huang, G. Vargas-Zuñiga, N. Busschaert, P.A. Gale, J.L. Sessler I. Shin, Chem, 2019, 5, 2079-2098; L.A. Jowett, E.N.W. Howe, V. Soto-Cerrato, W. Van Rossom, R. Pérez-Tomás and P.A Gale, Sci. Rep., 2017, 7, 9397; M. Perez-Hernandez, A. Arias, D. Martinez-Garcia, R. Perez-Tomas, R. Quesada, V. SotoCerrato, Cancers, 2019, 11, 1599;S. Zhang, Y. Wang, W. Xie, E.N.W. Howe, N. Busschaert, A. Sauvat, L. Gomes-da-Silva, G. Chen, I. Martins, L. Maiuris, O. Kepp, T. Soussi, P.A. Gale, N. Zamzami and G. Kromer, Cell Death \& Disease, 2019, 10, 242; L. Tapia, Y. Pérez, M. Bolte, J. Casas, J. Solà, R. Quesada and I. Alfonso, Angew. Chem. Int. Ed. 2019, 58, 12465-12468.

3 R. Quesada and R. Dutzler, J. Cystic Fibrosis, 2020, 19, S37-S41 A. Gianotti, V. Capurro, L. Delpiano, M. Mielczarek, M. GarciaValverde, I. Carreira-Barral, A. Ludovico, M. Fiore, D. Baroni, O. Mora, R. Quesada and E. Caci, Int. J. Mol. Sci. 2020, 21 1488; H. Li, H. Valkenier, A.G. Thorne, C.M. Dias, J.A. Cooper, M. Kieffer, N. Busschaert, P.A. Gale, D.N. Sheppard and A.P. Davis, Chem. Sci. 2019, 10, 9663-9672; H. Li, H. Valkenier, A.G. Thorne, C.M. Dias, J.A. Cooper, M. Kieffer, N. Busschaert, P.A Gale, D.N. Sheppard and A.P. Davis, Chem. Sci. 2019, 10, 96639672; X. Wu, L.W. Judd, E.N.W. Howe, A.M. Withecombe, V. Soto-Cerrato, H. Li, N. Busschaert, H. Valkenier, R. PerezTomas, D.N. Sheppard, Y.-B. Jiang, A.P. Davis and P.A. Gale, Chem, 2016, 1, 127-146; H. Li, H. Valkenier, L.W. Judd, P.R. Brotherhood, S. Hussain, J.A. Cooper, O. Jurček, H.A. Sparkes, D.N. Sheppard and A.P. Davis, Nat. Chem. 2016, 8, 24-32.

4 B.A. McNally, A.V. Koulov, T.N. Lambert, B.D. Smith, J.-B. Joos, A.L. Sisson, J.P. Clare, V. Sgarlata, L.W. Judd, G. Magro and A.P. Davis, Chem. Eur. J. 2008, 14, 9599-9606

5 S. J. Moore, C.J. Haynes, J. González, J.L. Sutton, S.J. Brooks, M.E. Light, J. Herniman, G.J. Langley, V. Soto-Cerrato, R. PérezTomás, Chem. Sci., 2013, 4, 103-117.

6 S. Hussain, P.R. Brotherhood, L.W Judd and A.P. Davis, A. P., J. Am. Chem. Soc. 2011, 133, 1614-1617.

7 C.M. Dias, H. Valkenier, and A.P. Davis, Chem. Eur. J. 2018, 24, 6262-6268

8 N. Busschaert, S.J. Bradberry, M. Wenzel, C.J.E. Haynes, J.R. Hiscock, I.L. Kirby, L.E. Karagiannidis, S.J. Moore, N.J. Wells, J. Herniman, G.J. Langley, P.N. Horton, M.E. Light, I. Marques, P.J. Costa, V. Félix, J.G. Frey and P.A. Gale, Chem. Sci., 2013, 4 3036-3045

9 N.J. Knight, E. Hernando, C.J.E. Haynes, N. Busschaert, H.J. Clarke, K. Takimoto, M. García-Valverde, J.G. Frey, R. Quesada and P.A. Gale, Chem. Sci., 2016, 7, 1600-1608.

10 P. Wang, X. Wu and P.A. Gale, Supramol. Chem. 2021, DOI: 10.1080/10610278.2021.1946539

11 S.E. García-Garrido, C. Caltagirone, M.E. Light and P.A. Gale, Chem. Commun. 2007, 1450-1452.
12 G.W. Rewcastle and W.A Denny, Synth. Commun. 1987, 17, 309-317.

13 C. Caltagirone, J.R. Hiscock, M.B. Hursthouse, M.E. Light, and P.A. Gale, Chem. Eur. J. 2008, 14, 10236-10243.

$14 \mathrm{http}: / /$ supramolecular.org

15 D.B. Hibbert and P. Thordarson, Chem. Commun. 2016, 52, 12792-12805.

16 R. Faure, J-.P. Galy, E.J. Vincent, A.M. Galy, J. and Barbe, J. Elguero, Spectroscopy Lett. 1983, 16, 431-439.

17 R. Faure, A. Mahamoud, J.-P. Galy, E.-J. Vincent, A.-M. Galy, and J. Barbe, Spectroscopy Lett. 1981, 14, 223-238.

18 C. Gao, F. Liu, X. Luan, C. Tan, H. Liu, Y. Xie, Y. Jin, and Y. Jiang, Bioorg. Med. Chem. 2010, 18, 7507-7514.

19 A. Boużyk, L. Jóźwiak, and J.Błażejowski J. Mol. Struct. 2002, 612, 29-38.

20 I.-S. Han Lee and C.-K. Lee, Bull. Korean Chem. Soc. 2007, 28 , 1067-1069.

21 J. Elguero, C. Marzin, A.R. Katritzky and P. Linda, Advances in Heterocyclic Chemistry, Suppl. 1, in The Tautomerism of Heterocycles. by A.R. Katritzky and A.J. Boulton, Academic Press, New York, San Francisco, London 1976, 299.

22 A. Boużyk, L. Jóźwiak, A. Wróblewska, J. Rak, J. Błażejowski, J. Phys. Chem. A 2002, 106, 3957-3963.

23 S. Issmaili, V. Pique, J.-P. Galy and R. Faure, Mag. Res. Chem. 1999, 37, 591-593.

24 L.K.S. von Krbek, C.A. Schalley and P. Thordarson, Chem. Soc Rev. 2017, 46, 2622-2637.

25 L.A. Jowett and P.A. Gale, Supramol. Chem., 2019, 31, 297312.

26 I.V. Tetko and V.Y. Tanchuk, ALOGPS 2.1 (http://www. vcclab. org) is a Free on-line Program to Predict $\log P$ and $\log S$ of Chemical Compounds.

27 I.V. Tetko, V.Y. Tanchuk, J. Chem. Inf. Comput. Sci. 2002, 42 1136-45.

28 N. Busschaert, P.A. Gale, C.J.E. Haynes, M.E. Light, S.J. Moore, C.C. Tong, J.T. Davis, W.A. Harrell Jr. Chem. Commun. 2010, 46 6252-6254.

29 N. Busschaert, I.L. Kirby, S. Young, S.J. Coles, P.N. Horton, M.E. Light, P.A. Gale, Angew. Chem. Int. Ed. 2012, 51, 4426-4430.

30 H. Valkenier, L.W. Judd, H. Li, S. Hussain, D.N. Sheppard and A.P. Davis, J. Am. Chem. Soc. 2014, 136, 12507-12512.

31 M. Boiocchi, L. Del Boca, D. Esteban-Gómez, L. Fabbrizzi, M. Licchelli and E. Monzani, Chem. Eur. J. 2005, 11, 3097-3104.

32 L.E. Karagiannidis, C.J.E. Haynes, K.J Holder, I.L. Kirby, S.J. Moore, N.J. Wells and P.A. Gale, Chem. Commun. 2014, 50, 12050-12053.

33 S. Altomonte and M. Zanda, J. Fluorine Chem. 2012, 143, 5793.

34 M.F. Sowaileh, R.A. Hazlitt and D.A. Colby, ChemMedChem 2017, 12, 1481-1490.

35 V. Saggiomo, S. Otto, I. Marques, V. Félix, T. Torroba and R. Quesada, Chem. Commun. 2012, 48, 5274-5276.

36 M.J. Spooner, and P.A. Gale, Chem. Commun. 2015, 51, 48834886.

37 N.J. Knight, E. Hernando, C.J.E. Haynes, N. Busschaert, H.J. Clarke, K. Takimoto, M. García-Valverde, J.G. Frey, R. Quesada and P.A. Gale, Chem. Sci. 2016, 7, 1600-1608.

38 N. Busschaert, S.-H. Park, K.-H. Baek, Y.P. Choi, J. Park, E.N.W. Howe, J.R. Hiscock, L.E. Karagiannidis, I. Marques, V. Félix, W. Namkung, J.L. Sessler, P.A. Gale and I. Shin, Nature Chemistry 2017, 9, 667-675.

39 S.-H. Park, S.-H. Park, E.N W. Howe, J.Y. Hyun, L.-J. Chen, I. Hwang, G. Vargas-Zuñiga, N. Busschaert, P.A .Gale, J.L. Sessler and I. Shin, Chem 2019, 5, 2079-2098.

40 M. Fares, X. Wu, D. Ramesh, W. Lewis, P.A. Keller, E.N.W. Howe, R. Pérez-Tomás and P.A. Gale, Angew. Chem. Int. Ed. 2020, 59, 17614-17621. 
41 X. Wu, J.R. Small, A. Cataldo, A.M. Withecombe, P. Turner, P.A. Gale, Angew. Chem. Int. Ed. 2019, 58, 15142-15147.

42 H. Valkenier, O. Akrawi, P. Jurček, K. Sleziaková, T. Lízal, K. Bartik and V. Šindelář, Chem 2019, 5, 429-444.

43 X. Wu, E.N.W. Howe and P.A. Gale, Acc. Chem. Res. 2018, 51 , $1870-1879$

44 X. Wu, L.W. Judd, E.N.W. Howe, A.M. Withecombe, V. SotoCerrato, H. Li, N. Busschaert, H. Valkenier, R. Pérez-Tomás, D.N. Sheppard, Y.B. Jiang, A.P. Davis and P.A. Gale, Chem 2016, 1, 127-146.

45 X. Wu and P.A. Gale, Chem. Commun. 2021, 57, 3979-3982.

46 Y. Yang, X. Wu, N. Busschaert, H. Furuta, and P.A. Gale, Chem. Commun. 2017, 53, 9230-9233.

47 M. Zarei, M. Vázquez Carrera, S. Vázquez Cruz, R. Leiva Martínez, E. Pujol Bech, 2017, Hri activators useful for the treatment of cardiometabolic diseases, WO2018010856A1. 